Saint Louis University School of Law

Scholarship Commons

All Faculty Scholarship

2009

\title{
Setting the Size of the Supreme Court
}

F. Andrew Hessick

Samuel P.Jordan

Follow this and additional works at: https://scholarship.law.slu.edu/faculty

Part of the Courts Commons, and the Supreme Court of the United States Commons 


\section{SetTING The Size OF THE SuPREMe COURT}

\section{F. Andrew Hessick ${ }^{\dagger} \&$ Samuel P. Jordan ${ }^{\ddagger}$}

As with any institutional feature, the size of the Supreme Court should be informed by a definition of functional goals. This article describes how the current size of the Supreme Court is largely untethered from any such definition, and it begins the process of understanding how size and Court performance might interact. To do so it identifies a list of institutional goals for the Supreme Court and explores how changing the size of the Court promotes or. obstructs the attainment of those goals. Given that the Court's institutional goals are numerous and occasionally in tension, there is no definitive answer to the question of how large the Court should be. Instead, the optimal size of the Court depends on how one views the relative importance of each institutional goal and how those goals should be balanced. Unfortunately; the current size of the Supreme Court is not attributable to a careful balancing of these institutional goals, but instead is due to political efforts to secure power on the Court. Consequently, a reconsideration of the Court's size in light of institutional considerations is long overdue.

\section{TABLE OF CONTENTS}

INTRODUCTION

I. THE GOAL OF THE SYSTEM?

A. Impartiality and Independence

B. Diversity and Representation.

C. Participation, Efficiency, Cohesion, and Accuracy.

$\uparrow \quad$ Associate Professor of Law, Sandra Day O'Connor College of Law, Arizona State University.

* Assistant Professor of Law, St Louis University School of Law. Thanks to Michael Berch, Paul Carington, Adam Chodorow, Joel Goldstein, Carissa Byrne Hessick, David Kaye, Amy Langenfeld, Angela Littwin, John V. Orth, Malcolm Stewart, Mary Sigler, Doug Sylvester, Anders Walker, Sean Williams, and to workshop participants at St. Louis University Law School, Arizona State University Sandra Day O'Connor College of Law, and the 2007 Law and Society Conference. Thanks also to Sandra Day O'Connor for helpful discussion and valuable feedback on this topic. Stephanie McCoy, Beth DiFelice, Mitch Newhouse, and John Schroeder provided excellent research assistance. 


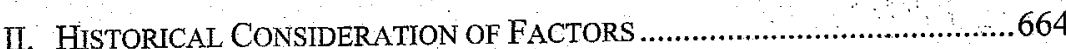

A. The Act of 1869 ........................................................................664

B. Roosevelt's Failed Expansion Effort.........................................671

III. COURT SIZE AND FUNCTIONALITY ..................................................673

A. Impartiality and Independence ................................................673

1. Impartiality .........................................................................673

2. Judicial Independence .......................................................675

B. Diversity, Representation, and Collegiality ................................678

C. Participation, Efficiency, Cohesion, and Accuracy ......................686

1. Efficiency and Expediency ................................................686

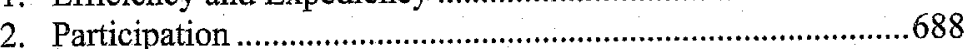

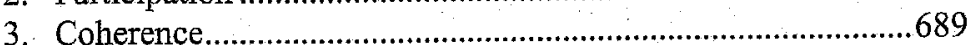

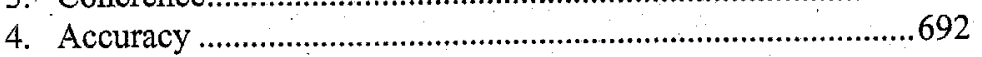

IV. WORKING TOWARDS THE IDEALLY SIZED COURT ...............................695

A. The Difficulty of Optimal Size .....................................................6...65

B. Size and Procedure ...............................................................699

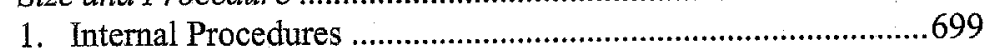

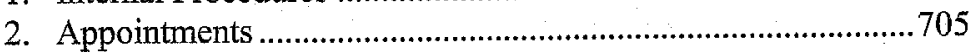

V. CONCLUSION

\section{INTRODUCTION}

How large should the Supreme Court be? The question is an important one-the Supreme Court has a central role in our legal and political system, and size is one of its critical institutional features-but answers are short in coming. ${ }^{1}$ The Constitution is not particularly helpful. Although it sets the size of the presidency and gives guidelines on the size of the two houses of Congress, ${ }^{2}$ the Constitution is silent when it comes to the size of the Court,

1. One exception is Lewis A. Kornhauser \& Lawrence G. Sager, Unpacking the Court, 96 YALE L.J. 82, 91-92 (1986), which begins the task of trying to ascertain the optimal size of the Court by arguing that a larger Court may increase the chance of providing "correct" judgments. This paper takes the next step by exploring how size bears on other institutional goals as well Another article on the topic is John V. Orth, How Many Judges Does It Take To gols as well An historical changes to the size of the Supreme Court. This paper focuses more on the institutional reasons for a particular size, rather than a historical description of the actual motivations for setting the size of the Court.

2. The Constitution sets the size of the presidency at one. It also prescribes a method for determining the number of senators-two per state. Although it does not prescribe a precise implicitly leaving the task to Congress. While Congress has dutifully heeded the assignment, it has virtually never focused on institutional design in doing so. Each of the six times ${ }^{3}$ that Congress has changed the size of the Court, the motivation was something other than a judgment about which size would be best for the Supreme Court as an institution. Thus, the 1869 expansion of the Court to its current nine members was accompanied by almost no Congressional discussion about functional considerations, but was prompted by a desire to solidify the Republican party's power on the Court and to correct a technical difficulty in the circuits. ${ }^{4}$

This article identifies considerations that should influence Court size. In doing so, the paper assumes that other institutional variables-such as the majority voting rule for deciding cases, the Court's tradition of always sitting en banc, and the practice of affirming without opinion when the Court is evenly divided--remain constant. ${ }^{5}$ It attempts to determine the institutional goals of the Supreme Court and how changing the size of the Court promotes or detracts from the attainment of those goals. It concludes that the Supreme Court does not have a single instititional goal, and the optimal Court depends on one's view about the relative importance of those goals and how they should be balanced. This article accordingly does not seek to answer the question of what constitutes the best size the Court should be for the simple reason that there is not a single best size.

That said, there are important reasons to understand the ways in which institutional goals and Court-size interact. How successfully the Court performs its tasks depends in large part on the particulars of its institutional design. ${ }^{6}$ For this reason, many of those dissatisfied with the Court have suggested institutional reforms. ${ }^{7}$ Up to now, those suggestions have stopped

method for calculating representatives, the Constitution does cap the number at one representive 30,000 people. U.S. CoNST. art. I, \& 2, cl. 3

3 See discussion infra Part II.A.

4 See discussion infra Part II.A.

5. There are countless other institutional features, such as, to name only a few more, life tenure; salary guarantees; the Court's control-over its docket; and the practices of issuing written opinions, of identifying the Justice who writes an opinion, and of conducting oral argument.

6. See e . Cass R. Sunstein \& Adrian Vermeule, Interpretation and Institutions, 101 MICH. L. REV. 885,920 (2003) (discussing how institutional design affects ability to interpret).

7. See, e.g., David J. Garrow, Mental Decrepitude on the U.S. Supreme Court: The Historical Case for a 28th Amendment, 67 U. CHI. L. REv. 995, 1086-87 (2000) (advocating compulsory retirement for Justices at age 75); Tracey E. George \& Chris Guthrie, "The Threes": Re-imagining Supreme Court Decisionmaking, 61 VAND. L. REV. 1825, 1854-55 (2008) (ancls); Jacob E. Gersen \& Adrian Verme Court should Ver (T) The Supreme Court, 1958 Term-Foreword: The Time Chart of the Justices, 73 HARV. L. REV. 
short of the fundamental question of size. This article brings that fundamental question into the discussion. Recognizing the relationship between size and the Court's performance as an institution is critical to facilitate a rational determination about how changing the size of the Court will affect the Court's institutional performance.

The article proceeds in four parts. Part I seeks to develop a list of the institutional goals of the Supreme Court. As with any institutional feature, the ideal size of the Court depends on what precisely we want the Court to accomplish. At the most abstract level, the Supreme Court's overarching purpose is to reach judicial decisions that are substantively and procedurally satisfactory to the public and other government actors. To achieve that purpose, we might value as instrumentally useful a number of institutional characteristics, including impartiality and independence; diversity; efficiency; and the ability to reach not only "correct" decisions, but also decisions that the lower courts and others can understand and apply. This list does not purport to be exhaustive. Nor is it necessarily internally consistent. ${ }^{8}$ In providing this list, Part I does not attempt to develop a normative account of how we might weigh competing characteristics, but instead simply canvasses the existing literature.

Part II demonstrates that the Court's current size of nine cannot be readily attributed to an effort by Congress to promote these, or any other readily identified, functional characteristics or to serve the Court's institutional purpose. It shows that the legislative record surrounding Congress's decision to increase the Court to nine contains hardly any mention of institutional concerns, and that the historical circumstances suggest that the increase was prompted principally by a desire to secure additional Republicans on the Court and to provide more Justices to ride

84,100 (1959) (arguing that the Court should take fewer cases); Kenneth W. Starr, The Supreme Court and Its Shrinking Docket: The Ghost of William Howard Taft, 90 MiNN. L. REV. $1363,1376-77$ (2006) (criticizing the certiorari pool); Adrian Vermeule, Should We Have Lay Justices?, 59 STAN. L. REV. 1569 (2007) [hereinafter Lay Justices] (arguing for adding nonlawyers to the Court); see also Letter from Dr. Paul D. Carrington, Professor, Duke University Law School, et al, to Joseph Robinette Biden, Jr., United States Vice President, et al. (Feb. 16, 2009), available at http://www.scotusblog.com/wp/wp-content/uploads/2009/02/judiciary-actof-2009.doc (recounting recent recommendations by Paul Carrington and 34 others to Congress for various institutional reforms for the Court); Frank B. Cross \& Stefanie Lindquist, The Decisional Significance of the Chief Justice, 154 U. PA. L. REV. 1665 (2006) (examining the

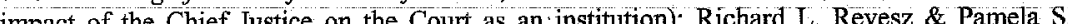
Karlan, Nonmajority Rules and the Supreme Court, 136 U. PA. L. REV. 1067 (1988) (discussing the effect of sub-majority voting rules on the Court).

8. For instance, insofar as one might seek diversity to create a sense of inclusion for minority groups by having their views represented on the Court, that goal may be in tension with the goal of impartiality. circuit. Part II also explains that in rejecting Roosevelt's Court-packing plan, the last serious congressional consideration of the size of the Court, Congress did not thereby conclude that nine is the best institutional size for the Court.

Part III returns to the discussion of institutional purpose and characteristics, and uses the social science literature on group decisionmaking to explore the impact of size. The number of Justices on the Court affects institutional characteristics-and thus the Court's institutional purpose, in various ways. Increasing size may result in functional improvements along a particular dimension-at least up to a point. For example, a larger Court might improve the likelihood of reaching substantively correct decisions because the additional Justices will increase the information available for making decisions; at some point, however, the size of the Court may become so large as to inhibit the productive exchange of information through deliberation, thus undercutting the informational benefits of larger size. Increasing size may also facilitate one goal while impeding others. For example, a larger Court might improve diversity but put pressure on coherence. In the end, the discussion in Part III is suggestive, but not definitive.

Part IV explains why there is no single answer to the question of ideal Supreme Court size. Not all of the various institutional goals are likely to be maximized at the same Court size. Some will be maximized on a relatively small Court, while others will require that the Court be relatively large. As a result, the best that one can do is to determine an optimal size with respect to a particular institutional vision. ${ }^{9}$ Answering the question of size requires first answering the question of which bundle of institutional goals is most valuable. This does not mean that the discussion of size is fruitless. It is useful to understand the connection between institutional goals and size as an institutional feature, because it allows for a more informed assessment in setting the size of the Court. Moreover, one can begin to make specific conclusions about the Court's size based on prevailing theories about the role of the Supreme Court in society, because they implicitly prioritize the institutional goals of the Court. Thus, for example, those, like Cass Sunstein, who think that the most important function of the Court is to reach

9. In this regard, it is interesting to note the differing sizes of the state supreme courts, which range in size from five to nine members. Compare, e.g., Alaska Court System, Supreme Court, http://www.state.ak.us/courts/ctinfo.htm\#supreme (five justices in Alaska), with, e.g., Alabama Judicial System Online, http://www.judicial.state.al.us/supreme.cfm (nine justices in Alabama Judicial System Online, http://www.judicial.state.al.us/supreme.cfm (nine justices in
Alabama). Although the size of each state supreme court may be due to non-institutional factors, at some level the variations may reflect differences in how states weigh various institutional considerations. 
the right answer in a particular case, should prefer a relatively large Court. ${ }^{10}$ By contrast, those, like Justice Scalia, who think that it is more important that the Court announce clear rules than that those rules be correct should favor a smaller Court. ${ }^{11}$ Finally, analyzing the interaction between size and performance may contribute to a better understanding of some of the Court's other features. ${ }^{12}$

\section{THE GOAL OF THE SYSTEM?}

An inquiry into the ideal design of an institution should begin with a discussion of institutional goals and purpose. ${ }^{13}$ The ultimate goal in designing the Supreme Court can be stated rather simply, if unhelpfully: We want the Court to reach decisions that are satisfactory and that are acceptable to the public and other governmental actors. ${ }^{14}$ Of course, the rub is defining what is satisfactory and what will ensure acceptance, and these are not simple questions.

Scholars and commentators have responded to these questions with a laundry list of characteristics that may be necessary or helpful to achieving the Court's ultimate goal. ${ }^{15}$ Unfortunately, and unsurprisingly, these characteristics do not present a consistent or cohesive set of design principles when taken together. To the contrary, they are often at odds with one another, and even where coexistence is possible, questions remain

10. CAss R. SUnSTEIN, ONE CASE AT A TTME ix-xi (1999).

11. Antonin Scalia, The Rule of Law as a. Law of Rules, 56 U. CHI. L. REv. 1175, 1179 (1989).

12. For example, some of the Court's internal procedures, such as the procedures controlling conferences, may be understood as a reaction to problems attributable in part to size.

13. See Kornhauser \& Sager, supra note 1, at 92 ("Before any satisfactory evaluation of a particular group decisionmaking process can be undertaken, a prior understanding of the nature of that group's proper purpose or purposes must be in place.").

14. See John A. Ferejohn \& Larry D. Kramer, Independent Judges, Dependent Judiciary: Institutionalizing Judicial Restraint, 77 N.Y.U. L. REV. 962, 974 (2002) (characterizing the "end" of institutional design as "the construction of a satisfactory process for adjudication").

"nd" of institutional design as "the construction of a satisfactory process for adjudication"). OF THE FEDERAL JUDICIARY 139-40 (2006) (informational diversity); Debra Lyn Bassett Judicial Disqualification in the Federal Appellate Courts, 87 IOWA L. REV. 1213, 1216 (2002) (impartiality); Richard H. Fallon, Jr., Legitimacy and the Constitution, 118 HARV. L. REV. 1787 , 1794 (2005) (noting the view that courts should reach "correct" decisions); Chad M. Oldfather, " 94 GEO L I. 121, 156 (2005) (pressing the imp 56 (2005) (pressing the importance of opinion. witing); Sherrilyn A. Ifll, Racial Diversity on the Bench: Beyond Role Models and Public Confidence, 57 WASH. \& LEE L. REV. 405, 480-81 (2000) [hereinafter Racial Diversity] (demographic diversity); Robert A. Leflar, The Multi Judge Decisional Process, 42 MD. L. REV: 722, 723 (1983) (extolling the importance of deliberation); Scalia, supra note 11, at 1179 (arguing that courts should write coheren opinions). about how to value the relative importance of each. This section makes no effort to resolve these tensions or to exhaust the field of possibilities, but instead presents a leading set of characteristics that might define a successful Supreme Court. ${ }^{16}$

\section{A. Impartiality and Independence}

Impartiality is perhaps the most fundamental and least controversial requirement of a successful Supreme Court. Indeed, the oath of judicial office includes a pledge to "administer justice without respect to persons, and do equal right to the poor and to the rich, and [to] ... faithfully and impartially discharge and perform [his or her] . . . duties." ${ }^{17}$. The Court has trumpeted the importance of impartial adjudication on numerous occasions, ${ }^{18}$ and academics of all stripes have echoed the refrain. ${ }^{19}$ But just what is meant by impartiality is not entirely self-evident, and for that reason there is at least a danger that its unanimous embrace reflects the term's lack of meaningful content rather than deep agreement as to its particulars. ${ }^{20}$

That said, there does seem to be basic agreement about much of what impartiality demands. One area of agreement is that impartiality involves the absence of both actual and perceived bias. ${ }^{21}$ Actual bias - that is, when a

16. Although not within the scope of this paper, it is worth noting briefly that different considerations may apply to the en banc procedures of circuit courts. Outside the Ninth Circuit, the en bane court in each circuit consists of all the active judges on the circuit (though some circuits also allow a senior circuit judge to sit en banc if he was a member of the panel that originally heard the case). The size of the en banc court aecordingly depends on the number of judges on the court. The number of judges on a circuit court is due more to the need to ensure that there are adequate judges to hear all the panel cases than to institutional consideration the twenty-seven judges sit en banc, though in exceptional circumstances the entire court may sit. 9TH CIR. R. 35-3.

17. 28 U.S.C. $\S 453(2006)$.

18. In re Murchison, 349 U.S. 133 (1955); Offutt v. United States, 348 U.S. 11 (1954); Joint Anti-Fascist Refugee Comm. y. McGrath. 341 U.S. 123, 171-72 (1951) (Frankfurter, J., concurring); Liteky v. United States, 510 U.S. 540 (1994).

19. See; e.g., Bassett, supra note 15 , at 1216 ("[F] $]$ airness and impartiality are concepts central, and essential, to maintaining public support for, and confidence in, our courts ...."); Amanda Frost, Keeping Up Appearances: A Process-Oriented Approach to Judicial Recusal, 53 U. KAN. L. Rev. 531, 537 (2005); Sherrilyn A. Ifill, Judging the Judges: Racial Diversity, Impartiality and Representation on State Trial Courts, 39 B.C. L. REV. 95, 97 (1997) [hereinafter Judging the Judges].

20. See Ferejohn \& Kramer, supra note 14, at 962-63 (noting that statements that garner universal approval often do so because they are "as vapid as they are axiomatic").

21. Offutt, 348 U.S. at 14 ("IJ]ustice must satisfy the appearance of justice."); Bassett, supra note 15, at 1219 ("[T]he necessity of judicial impartiality encompasses both actual and perceived biases."). 
judge is prejudiced against a particular outcome ${ }^{22}$ - leads to unjust decisions and undermines public confidence in the judiciary, ${ }^{23}$ perceived bias does the latter if not the former. ${ }^{24}$ Both have been understood to have a constitutional dimension. ${ }^{25}$

In terms of formal requirements, the bedrock conception of impartiality is that decision-makers have no personal interest in the outcome of a case. ${ }^{26}$ Where a conflict of interest is present, the potential for actual bias is very high, and a perception of bias will almost certainly exist even where actual bias does not. ${ }^{27}$ The desire to avoid such conflicts has led to some clear and longstanding recusal rules. For instance, the rule that "[n]o man shall be a judge in his own case" dates back to at least the seventeenth century; ${ }^{28 .}$ and was incorporated into American practice within three years of the Constitution's ratification. ${ }^{29}$ Similarly, the rule that a judge may not "hear or determine an appeal from the decision of a case or issue tried by him" has been a fixture of federal recusal statutes since the Judiciary Act of $1891^{31}$

22. BLACK'S LAW DICTIONARY 171 (8th ed. 2004) (defining "bias" as an "[i]nclination; prejudice; predilection")

23. See, e.g., Frost, supra note 19, at 565 ("An impartial decisionmaker is essential to the legitimacy of any system of adjudication."); Martin H. Redish \& Lawrence C. Marshall, Adjudicatory Independence and the Values of Procedural Due Process, 95 YALE L.J. 455, 47677 (1986).

24. RichaRd E. FlamM, Judicial DISQUALIFICATION: ReCusal AND DisQualification OF JUDGES \& 5.4.1 (1996) ("Since an appearance of bias may be just as damaging to public confidence in the administration of justice as the actual presence of bias, actuct giving the appearance of bias should generally be avoided in the same way as acts or

inexorably bespeak partiality."); see also Redish \& Marshall, supra note 23 , at 483 .

25. See In re Murchison, 349 U.S. 133, 136 (1955) (due process requires absence of actual bias); Tumey v. Ohio, 273 U.S. 510,533 (1927) (finding due process

26. Republican Party of Minn. v. White, 536 U.S. 765, 788 (2002) (O'Connor, J., ("We of course want judges to be impartial, in the sense of being free from any persor stake in the outcome An Unholy Alliance: The Ex Parte Relationship Between the Judge and the Prosecutor, 79 NEB. L. REY. 251, 263 (2000) ("Independence requires the court to have no interest in the outcome of the case.").

27. See Caperton v. A.T. Massey Coal Co., 129 S. Ct. 2252, 2260 (2009).

28. See Dr. Bonham's Case, (1608) 77 Eng. Rep. 638 (K.B.).

29. Act of May 8,1792 , ch. $36,11,1$ Stat. 278-79 (1792). The rule created by the Act required recusal only where the judge had a financial inierest in the litigation or had served as counsel to a party. The nule was later broadened to require recusal where the judge's counsel to a party. The rule was later broadened to require recusal where the judge's relationship with an attorney made it improper to hear the case. Act of Mar. 3,1911 , ch. 231 ; $\S$
20,36 Stat. 1087,1090 (codified as amended at 28 U.S.C. $\S 20$ (1992)). For a discussion of the development of recusal standards, see Frost, supra note 19, at 537-50.

30. 28 U.S.C. $\$ 47(2006)$

31. 26 Stat. 827 , art. 3 .
Even where no conflict of interest is present, other forms of bias may be present. For example, a judge who simply dislikes one of the parties for a reason unrelated to the case is presumed not to be impartial. ${ }^{32}$ Guaranteeing impartiality thus requires something more than policing conflicts of interest. But the precise forms of bias that violate impartiality are contestable; it is here that the universal embrace of impartiality falters. ${ }^{33}$ Ideology, for example, is a commonly accepted bias. ${ }^{34}$ Moreover, objective identification of bias is difficult even when agreement exists. ${ }^{35}$ As a result, the standards that apply to Supreme Court Justices; as to all federal judges, are frustratingly unclear. ${ }^{36}$

32. See David Blanck, The Appearance of Justice Revisited, 86 J. CRIM. L. \& CRIMINOLOGY 887, 901-04 (1996); Jeffrey M. Shaman, Bias on the Bench: Judicial Conflicts of Interest, 3 GEO. J. LEGAL ETHICS 245, 250 (1989) ("A feeling of ill will or, conversely, favoritism toward one of the parties to a suit . constitute disqualifying bias ...."). On the other hand, when the basis for the judge's dislike of one party is internal to the case at hand, the resulting bias is generally considered acceptable. See Liteky v. United States, 510 U.S. 540 $550-51$ (1994) ("The judge who presides at a trial may, upon completion of the evidence, be exceedingly ill disposed towards the defendant, who has been shown to be a thoroughly reprehensible person. But the judge is not thereby recusable for bias or prejudice, since his pon the proceedings, and are indeed sometimes (as in a bench trial) necessary to completion of the judge's task."); Shaman, supra at 251-52. But see Cobell v. Kempthome, 455 F.3d 317, 335 (D.C. Cir. 2006) (removing district judge because proceedings resulted in "hostility" that disabled judge from "render[ing] fair judgment"); Adam J. Safer, The Illegitimacy of the Extrajudicial Source Requirement for Judicial Disqualification Under 28 U.S.C. $\$ 455(a), 15$ CARDOZO L. REV. 787, 813 (1993).

33. See W. Bradley Wendel, Jurisprudence and Judicial Ethics (Cornell Law Sch. Legal Studies Research, Working Paper No. 08-009, 2007), available at

http://papers.ssm.com/sol3/papers.cfm?abstract_id=1024316.

34. See Richard Delgado, Rodrigo's Committee Assignment: A Skeptical Look at Judicial Independence, $72 \mathrm{~S} . \mathrm{CAL}$. L. REV. 425, 434 (1999) ("Most judges are . . moderate in their social and political views. No one considers this an affront to judicial independence, although it has a tremendous influence on how cases are decided."). Indeed, the Framers arguably sought to introduce ideological bias into the Supreme Court. See JACK N. RAKOVE, ORIGINAL MEANINGS: PoLITICS AND IDEAS IN THE MAKING OF THE CONSTITUTION 328 (1996)

35. See Shaman, supra note 32 , at 250 ("Bias and prejudice ... tend to be subjective, and their external indicia are relatively difficult to determine precisely."). The confusing nature of the formal recusal standards does not help in this regard. See supra note 32.

36. 28 U.S.C. $\$ 455$ (2006) (mandating recusal whenever a judge's "impartiality might reasonably be questioned"). For criticisms, see Sarah M. R. Cravens, In Pursuit of Actual Justice, 59 ALA. L. REV. 1, 8 (2007) ("The terms of . . 28 U.S.C. $\$ 455$. . are vague at best in their guidance....") Frost, supra note 19, at 538 (noting that "no universal form rule or procedure for recusal exists"). A related problem is that these standards depend on subjective procedure for recusal exists"). A related problem is that these standards depend on subjective Procedural Void in the Court of Last Resort, 57 RuTGERs L. REV. 107, 137 (2004) ("[F]ederal law requires judges in the federal system to make judgments about their own impartiality. 
However defined, the case-by-case bias inquiry does not represent the full extent of our concerns about impartiality. The Constitution contains structural features designed to promote impartiality through institutional independence. Article III guarantees life tenure to the Justices and prohibits reduction of their salaries. ${ }^{37}$. These structural features were intended to permit judges to resolve cases without being influenced by fear of reprisal from the parties, ${ }^{38}$ or by undue pressure from external sources. ${ }^{39}$ Alexander Hamilton viewed them as "one of the most valuable of the modern improvements in the practice of government." 40

Still, the commitment to judicial independence is not completeCongress may impeach Justices and exercise influence in more subtle forms ${ }^{41}$ - and has been the subject of regular criticism even in its incomplete form. ${ }^{42}$ Nevertheless, it seems clear that some basic level of independence is valued as a means of promoting impartial decision-making.

37. U.S. CONST. art: III, $\S .1$ ("The Judges, both of the supreme and inferior Courts, shall hold their Offices during good Behaviour, and shall, at stated Times, receive for their Services, a Compensation, which shall not be diminished during their Continuance in Office.").

38. John Ferejohn, Independent Judges, Dependent Judiciary: Explaining Judicial Independence, 72 S. CAL. L. REV. 353, 369 (1999) (" $[T]$ he reason for seeking judicial independence is to permit the judicial process to be appropriately insensitive to arbitrary and irrelevant influences ... ."); see also Ferejohn \& Kramer, supra note 14, at 972 ("Judicial independence seeks first and foremost to foster a decisionmaking process in which cases are decided on the basis of reasons that an existing legal culture recognizes as approptiate."). The constitutional structure was intended to insulate the judiciary not just from institutional pressures from other branches of the government, but also from the people themselves. Ferejohn \& Kramer, supra note 14 , at $968-70$.

39. Most importantly, structural independence allows a judge to decide cases involving governmental actors without receiving undue pressure from those actors. See, e.g., Stephen G. Breyer, Judicial Independence in the United States, 40 ST. LouIS U. L.J. 989, 989 (1996) ("The question of judicial independence revolves around the theme of how to assure that judges decide according to law, rather than according to their own whims or to the will of the political (Kennedy, J., concurring) (declaring order establishing adjudications by military commissions unconstitutional because of executive influence over adjudications). Even in cases not involving the government, structural independence remains valuable as a shield from private interests that may manifest themselves through political mechanisms.

40. THE FEDERALIST No. 78, at 522 (Alexander Hamilton) (Jacob E. Cooke ed., 1961).

41. U.S. CONST. art. III \&. 1. See generally Ferejohn, supra note 38, at 354-55 ("Our commitment to democratic values... requires that we provide a way by which judges can be made at least somewhat accountable, directly or indirectly, to the people or their representatives."). As Larry Kramer and John Ferejohn describe, the need for some level of accountability while preserving impartiality has resulted in a system where the judiciary as a whole is susceptible to political pressures while individual judges are generally free from those pressures. See Ferejohn \& Kramer, supra note 14, at 969-971.

42. In the founding era, this criticism was lodged most forcefully by the Anti-Federalis Brutus, who complained that under the Constitution judges "are to be rendered totally independent, both of the people and the legislature . . . . No errors they may commit can be

\section{B. Diversity and Representation}

There are at least two forms of the argument for diversity on the Supreme Court. The first maintains that greater diversity on the Court may increase the public trust in the Court. According to this argument, increasing demographic diversity may convey a sense of inclusion to demographic groups that would otherwise be unrepresented on the Court, and that sense of inclusion may in turn generate greater public confidence in the Court. The second argument focuses on diversity as a means for improving the Court's decisions. This argument maintains that increasing the diversity of information and viewpoints held by the Justices will increase the total information on the Court, which will lead to more informed, and thus better, decisions.

When Sandra Day O'Connor indicated her intent to retire from the Supreme Court in 2005, President Bush received significant pressure to appoint a female or Hispanic Justice to replace her. ${ }^{43}$ President Obama received perhaps even greater pressure leading up to the nomination of Sonia Sotomayor to replace the retiring Justice David Souter. ${ }^{44}$ These episodes were the latest in a long line of efforts seeking to increase demographic diversity on the Court. The essential claim for demographic diversity is "that diversity matters on the Court and that the Court should be a demographically representative body of the citizens of the United States." ${ }^{.45}$

corrected by any power above them ... nor can they be removed from office for making ever so many erroneous adjudications." ESSAYS OF BRUTUS, NO. XI (Jan. 31, 1788), reprinted in THE ANTI-FedERALIST PAPERS aND the CONSTITUTIONAL CONVENTION DEBATES, at 293 (Ralph Ketcham ed., 1986). More recently, critics have attacked the independence protections as a

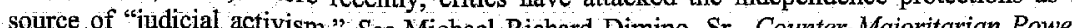
and Judges'Political Speech, 58 FLA L. and Judges Political Speech, 58 FLA. L. REV. 53, 61-62 (2006) ("[1]f judges follow their own preferences instead of the law, judicial independence is destructive, not only of democracy, but also of the rule of law.").

43. See Angela Onwuachi-Willig, Representative Government, Representative Court? The Supreme Court as a Representative Body, 90 MinN. L. REV. 1252, 1254 n.17 (2006).

44. For example, Roberta Liebenberg, who heads the Commission on Women in the Profession, argued that "it's incredibly timely and important that the president replace Justice Souter with a woman, and hopefully more women to come, so that the court will be representative of women in the profession." Charlie Savage, Opportunities Rising for Women N.Y. TIMES, May 2, 2009, at A1. Similarly, Hispanic groups put pressure on Obama to select Hispanic nominee. See, e.g., Linda Feldmann, Hispanics Püsh Obama for a Supreme Cour $\begin{array}{lllll}\text { Seat; CIRISTIAN SCIENCE MONITOR, May } & \text { 8, 2009, }\end{array}$ htp//eatures.csmonitor.com/politics/2009/05/08/hispanics-push-obama-for-a-supreme-courtseat/ (describing a letter sent by the Congressional Hispanic Caucus to President Obama even before Justice Souter's announced retirement).

45. Onwuachi-Willig, supra note 43 , at 1258 . 
But why exactly does diversity matter? One possibility is that the inclusion of various segments of society provides a token of inclusion in the legal machinery of the United States. The Supreme Court has symbolic status associated with its position at the head of the American legal system. The appointment of a Justice from an unrepresented demographic group may convey a sense of representation. Various "firsts" on the Supreme Court - most notably the additions of Thurgood Marshall and Sandra Day $O^{\prime}$ Connor and most recently the addition of Sonia Sotomayor-have been celebrated at least in part because of their symbolic inclusion of previously unrepresented demographic groups. ${ }^{46}$

The claim for value based on demographic diversity is not necessarily limited to the symbolic presence of diverse individuals. ${ }^{47}$ Demographic

46. When announcing Marshall's nomination, President Johnson remarked that it was "the right thing to do, the right time to do it, the right man and the right place." John P. MacKenzie, Thurgood Marshall, in 4 THE JUSTICES OF THE UNTTED STATES SUPREME COURT, 1789-1969: THEIR LIVES AND MAJOR OPINTONS 3063, 3064 (Leon Friedman \& Fred L. Israel eds., 1969); see also Kevin R. Johnson, On the Appointment of a Latinalo to the Supreme Court, 13 LA RAZA L.J. 1, $3(2002)$ ("The nomination of an African American alone represented an achievement for the entire African American community, unmistakably signaling that it in fact is an important part of the nation as a whole."). President Reagan's nomination of $O^{\prime}$ Connor fulfilled a campaign promise to add to the Supreme Court "the most qualified woman that [he] could possibly find." Ronald Reagan, U.S. President, Remarks Announcing the Intention to Nominate Sandra Day O'Connor to be an Associate Justice of the Supreme Court of the United States his speech announcing the Sotomayor nomination, President Obama noted that "what you've shown in your life is that it doesn't matter where you come from, what you look like, or what challenges life throws your way-no dream is beyond reach in the United States of America." Barack Obama, U.S. President, Remarks by the President in Nominating Judge Sonia Sotomayor to the United States Supreme Court (May 26, 2009), http://www. whitehouse.gov/the press_office/Remarks-by-the-President-in-Nominating-JudgeSonia-Sotomayor-to-the-United-States-Supreme-Court.

Other examples of symbolic appointments include Justice Brandeis, the first Jewish Justice, see ThOMAS KarfunKel \& ThOMAS W. RYLeY, THE JeWISH SEAT: ANTI-SEMTTISM AND THE APPOINTMENT OF JEWS TO THE SUPREME COURT 144 (1978), and Justice Scalia, whom Presiden Reagan appointed in part because he would be the Court's first Italian-American Justice. See, e.g., Sheldon Goldman, The Politics of Appointing Catholics to the Federal Courts, 4 U. ST. THOMAS L J 193, 200 (2006). Not all "firsts" however, are done for symbolic reasons. Roger Tancy's appointment to the Court Tancy's appo inclusion. See Christine L. Nemacheck, Have Faith In Your Nominee? The Role of Candidate Religious Beliefs in Supreme Court Selection Politics, 56 DRAKE L. REV. 705, 720 (2008) However, the presence of a Catholic Justice on the Court eventually obtained a symbolic value See Harold B. Hinton, President Chooses Clark for the Supreme Court, M'Grath for Attorney General, N.Y. TIMES, July 29, 1949, at C1 (noting surprise that President Truman did not appoint a Catholic to succeed Catholic Justice Frank Murphy)

47. Limiting the value of diversity to symbolic inclusion has met much criticism. See, e.g. Racial-Diversity, supra note 15, at 480 ("A black 'role model' judge is credited solely for being diversity has an instrumental dimension as well: It may lead to increased public acceptance of the Court's decisions. This acceptance argument for diversity is essentially the echo of inclusion. If the appointment of a Hispanic Justice conveys to Hispanics that they are full members of the legal system, ${ }^{48}$ then Hispanics - and even non-Hispanics who value inclusion-may respond by placing greater trust in the legal system. ${ }^{49}$ Similar arguments may be made for diversity along a different axis, such as geography, economic station, or even age. From the perspective of convincing invested members of the judicial or political establishment to embrace diversity, the acceptance argument is perhaps more persuasive than the more extrinsic inclusion argument because it is rooted in self-interest. And it is more satisfying to those who believe that diversity produces something more than symbolic value. ${ }^{50}$ But like the inclusion argument, the acceptance argument stops short of claiming that the pursuit of diversity generates a positive effect on the way that the Supreme Court actually functions. ${ }^{51}$

But other diversity arguments make precisely that sort of claim. ${ }^{52}$ These claims consist of two steps: first, that the tendency for judges from diverse backgrounds to view cases differently will introduce new perspectives in the decision-making process, and second, that decision-making will be enhanced by the introduction of those new views and perspectives. ${ }^{53}$ Under

black and inspiring others, rather than assessed for his competence, performance or effectiveness as a representative.")

48. Many arguments for adding a Hispanic Justice have been rooted precisely in this value of inclusion. See, e.g., Johnson, supra note 46, at 2 (arguing that the addition of a Latino/a to the Supreme Court "would send a powerful message of inclusion").

49. See, e.g., Kevin R. Johnson \& Luis Fuentes-Rohwer, A Principled Approach to the Quest for Racial Diversity on the Judiciary, 10 MrCH. J. RACE \& L. 5, 28 (2004) ("By making an important decision-making institution more representative of the greater community, a diverse judiciary fosters the legitimacy of the courts among the public."); Onwuachi-Willig, supra note 43 , at 1264 (" $[T]$ he rulings of the Court would carry more weight and contain greater authority f they were viewed as coming from a body that was comprised of a cross-section of the nation.").

50. Others feel that even acceptance does not go far enough because it "bases the value of diversity on the questionable aim of strengthening the appearance of justice, rather than on the goal of increasing actual fairness in the administration of justice." Ifill, supra note 15, at 481 .

51. While often made in connection with inclusion or acceptance arguments, the instrumental claim for diversity is distinct. Even if a homogenous Court were to function in the same way that a diverse Court does, the latter might still enjoy the benefits associated with inclusion and acceptance.

52. See, e.g., SUNSTEIN, supra note 15 , at 140.

53. See id (" $[\mathrm{D}] \mathrm{D}$ iverse views, on any particular panel, are likely to ... produce outcomes, and arguments, that are different and better [because] they include a mix of perspectives."); Ruth Bader Ginsburg, The Supreme Court: A Place for Women, 32 Sw. U. L. REv. 189, 190 (2003) ("A system of justice is the richer for the diversity of background and experience of its 
this view, we would prefer the appointment of a Hispanic Justice because "a member of a previously excluded group can bring insights to the Court that the rest of its members lack, ${ }^{, 54}$ and we would explicitly hope that decisional outcomes would improve as a result. ${ }^{55}$ Separate and apart from their symbolic value, the appointments of Justices Marshall, O'Connor, and Sotomayor have been celebrated on this basis. ${ }^{56}$

This conception of diversity's value carries several implications worth mention. First, because this value is untethered from symbolism, it broadens the definition of diversity itself. If the value of diversity is symbolic inclusion, then the only forms of diversity we value are those whose symbolism matters. Certain forms of diversity-diverse employment experience, say-would not necessarily be pursued under a symbolic inclusion view of diversity because there is little, if any, symbolic gain stemming from the pursuit. But if the diversity argument is instead rooted in the value of differing perspectives, then career diversity may indeed be a

participants."); Onwuachi-Willig, supra note 43, at 1263 ("Adding a diversity of voices ... will only enrich the decision-making process.").

54. Barbara A. PERRY, A "RePRESENTATIVE" SUPREME COURT? THE IMPACT OF RACE, RELIGION, AND GENDER ON APPOINTMENTS 137 (1991) (paraphrasing interview remarks made by Justice Lewis F. Powell, Jr. in a 1986 interview).

55. One could make a diversity argument that includes the first claim but not the second. We might view the introduction of diverse viewpoints and perspectives into the decisionmaking process as valuable-and perhaps even necessary-even if that introduction has some negative impact on decisional outcomes. Judge Posner has come close to this when he argues that diversity in the judiciary is necessary to preserve legitimacy, even if it comes at the cost of legal determinacy. RiCHARD A. POSNER, LAW, PRAGMATISM, AND DEMOCRACY 94 (2003).

56. The celebration of this effect of diversity has not been uniform, however. For example, Justice Sotomayor's frank acknowledgement of the influence of her background on her decision-making was a primary source of criticism for those opposing her confirmation. See Ross Douthat, Race in 2028, N.Y. TIMES, Jul. 20, 2009, at A19, available at http://www.nytimes.com/2009/07/20/opinion/20douthathtml ("During last week's Supreme Court confirmation hearings, Republican senators kept bringing the conversation back to 2001 - the year when Sonia Sotomayor delivered the most famous version of her line about how a 'wise Latina woman with the richness of her experiences' might outshine a white male judge.") Republicans Press Judge About Bias and Activism, N.Y. TIMES, Jul. 15, 2009, at A1, available at http://www.nytimes.com/2009/07/15/us/politics/15confirm.html (describing Republican criticism).

Notably, much of the celebration comes from other Justices, who stand most able to observe this value. See, e.g., William J. Brennan, Jr., A Tribute to Justice Thurgood Marshall, 105 HARV. L. REv. 23, 23 (1991) (attributing Justice Marshall's uniqueness as a Justice to the "special voice that he added to the Court's deliberations and decisions"); Byron R. White, $A$ Tribute to Justice Thurgood Marshall, 44 STAN. L. REV. 1215, 1216 (1992) ("[Justice Marshall] would tell us things that we knew but would rather forget; and he told us that we did not know due to the limitations of our own experience."). desirable goal. ${ }^{57}$ Second, the value here is based on the contributions rather than the mere identities of diverse individuals. As a result, individuals are expected to represent various perspectives and views, and those who fail to do so may not be considered diverse, notwithstanding their objectively diverse characteristics. Thus, many proponents of diversity have mixed feelings about Clarence Thomas, who is unobjectionable as the successor to Justice Marshall on a symbolic inclusion view, but controversial at best on a representational view. ${ }^{58}$

In short, there are at least two forms of the argument for diversity on the Supreme Court: diversity as inclusion, and diversity as proxy for values and views. Both arguments have been regularly invoked by those who seek to increase the Court's diversity. But they do not completely overlap in terms of the kinds of diversity that are pursued, or the way that the pursuit is evaluated.

\section{Participation, Efficiency, Cohesion, and Accuracy}

A final set of features relate to the Court's ability to function effectively, both in terms of its internal operation and its external role in the overall administration of the judicial system. At a minimum, effective internal operation means that the Court is able to decide its cases in a timely fashion and at a reasonable cost. Although concerns of these sorts are raised with some regularity in the context of the lower courts, ${ }^{59}$ they are rarely invoked

57. For this reason; Professor Epstein and others have argued in favor of career diversity on the Supreme Court. Lee Epstein, Jack Knight \& Andrew D. Martin, The Norm of Prior Judicial Experience and Its Consequences for Career Diversity on the U.S. Supreme Court, 91 CAL. L. REV: 903, 956 (2003) ("Because judges with varied career experiences bring distinct CAL. L. REV: 903,956 (2003) ("Because judges with varied career experiences bring distinct
perspectives to the bench-perspectives that ultimately lead them to make distinct judicial choices-merging jurists with diverse career paths on a particular Court ought ... lead to more effective decision making:"); see also Lay Justices, supra note 7, at 1586-91 (offering similar reasons for adding non-lawyer Justices). Although her argument is instrumental, Epstein does cote note that caree diversity will have a secon diversity by expanding the relevant applicant pool. Epstein, Knight \& Martin, supra at 956-60.

58. See, e.g., Johnson \& Fuentes-Rohwer, supra note 49, at 14 ("During his confirmation hearings, Justice Thomas testified that he would speak on behalf of the forgotten, just as Justice Marshall had done. Thirteen years into his tenure on the court, it is far from self-evident that he has done so."); see also Walter Barthold, Book Review, 8/15/2007 N.Y.L.J. 2, (col. 5) (2007) (reviewing (I Thomas)

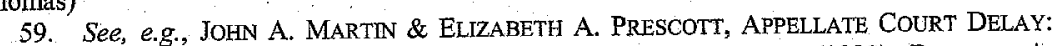
Structural Responses to tHe Problems of Volume and Delay (1981); Richard A POSNER, THE FEDERAL COURTS: CHALLENGE AND REFORM 124-59 (1996). (discussing the federal case load crisis and its consequences on the effective performance of the court system) 
in modern discussions of the Supreme Court. This is largely due to the Court's success in this domain, which is attributable to the near-total control the Court currently exercises over its docket. ${ }^{60}$ But the ability of the Court to clear this basic functionality hurdle has not always been taken for granted, as evidenced by the central role that functionality concerns played in Congress's decision to create the circuit courts of appeal in 1891.61

Effective internal operation may also mean that the decisions are reached in a certain way. For example, we may want to ensure that each Justice participates meaningfully in the decision. Meaningful participation requires more than physical presence during the decision-making process. Instead, it might require that each Justice actually participates in an exchange of views, or it might merely require an opportunity for participation. In either case, acceptable contributions could be either formal (i.e., asking questions at oral argument or writing separate opinions) or informal (i.é., expressing views during conference or making comments on circulated drafts) ${ }^{62}$ Similarly, we may want to take steps to ensure that the deliberation among Supreme Court Justices is civil and productive. This may go beyond a mere requirement that each Justice participates in some way:

A different set of effective internal operation concerns relate to transparency and candor. Many commentators have argued that the Court's legitimacy and authority derive in large part from the persuasive power of its publicly stated reasons for its decisions. ${ }^{63}$ This argument holds only if

60. Aside from a small set of cases over which the Supreme Court has compulsory appellate jurisdiction, the Court has discretionary certiorari jurisdiction over which cases to hear. See, e.g., Daniel J. Meltzer, Jurisdiction and Discretion Revisited, 79 NOTRE DAME L. REV. 1891, 1896-1900 (2004). Indeed, the main source of recent caseload concerns relative to the Supreme Court has been the relatively small number of cases being heard and decided. See Richard A. Posner, The Supreme Court, 2004 Term-Foreword: A Political Court, 119 HARV. L. REV. 31, 66-67. (2005)

61. See Judiciary Act of 1891 , ch. 517,26 Stat. 826 (1891). Congress created the circuit courts of appeal to free the Justices from the burden of circuit riding; this reduced the Justices' workloads, which in turn reduced delays in decisions by the Supreme Court. See David R. Stras, Why Supreme Court Justices Should Ride Circuit Again, 91 MINN. L. REv. 1710, 1721-26 (2007):

62. See Robert A. Leflar, The Multi-Judge Decisional Process, 42 MD. L. REV. 722, 723 (1983) ("I]t is the duty of all the judges on a multi-judge court to participate actively in the joint judicial enterprise which justifies their jobs. ... If decisions and opinions do not truly represent this aggregate of the judges' views, the basic justifications for the multi-judge appellate system are disregarded."').

63. See Chad M. Oldfather, Defining Judicial Inactivism: Models of Adjudication and the Duty to Decide, 94 GEO. L.J. 121, 156 (2005) ("[T] he judiciary's legitimacy and authority depend largely on its ability to persuasively explain and justify its decisions."); Micah Schwartzman Judicial Sincerity, 94 VA. L. REV. 987, 990-91 (2008) ("Judicial] decisions are justification. It must be defended in a way that those who are subject to it can, at least in the Court candidly states the principles uno Transparency further promotes legitimacy by provh greater access to the decision-making process to satisfy candor. ${ }^{65}$

As for external operation relating to the administration of the ultimate goal is a system that promotes "procedural rat meaning that participants are able "to engage in rational plannins their situation, to make informed choices among options."67 At the Sup Court level, this leads to a claim that the Court, because of its position at $t_{2}$ top of a considerable judicial hierarchy and its inability (or unwillingness) to review a significant percentage of cases decided by other courts within that hierarchy, should issue decisions that effectively manage the behavior of lower courts and of potential participants in the legal system. ${ }^{68}$

principle understand and accept. To determine whether a given justification satisfies this principle, understand and accept. To determine whether a given decisions."); Kathleen M requirement, judges must make public the legal grounds for their decisions."), Kathleen $\mathrm{U}$ Sullivan, Post-Liberal
REv. 293, 297 (1992).

64 . Indeed, proponents of candor in judicial decision-making often include Supreme Court Justices as a source of intentional-and undesirable - obfuscation. See MARTIN SHAPIRO, LAW Justices as a source of intentional-ant: NEW APPROACHES TO POLITICAL JURISPRUDENCE 250-52 AND POLITCS IN The SUPt's insincere use of a "selayed action' approach").

65.

65. Brian Galle \& Mark Seidenfeld, Adminstrative Lactice lament the secreey that shrouds 1953 (2008). Many critics of modern Supreme Court practice lament the secrecy that shroud the decision-making process. See ELL.IOTT E. SLOTNICK \& JENNIFER A. SEGAL, TELEVISION NeWS AND THE SUPREME COURT: All tHe News THAT's FIT TO AIR? 239-40 (1998). Proposals for improving the Court's operational transparency percolate regularly. See LORRAINE H. TONG Tor im TELEVISING
ISSUES, CRS REPORT FOR CONGRES, 16 (2006), available at http://www.fas.org/sgp/crs/secrecy/RL33706.pdf (proposing that Supreme Court arguments be televised). The Justices, however, have largely resisted these efforts. See, e.g., On Cameras in Supreme Court, Souter Says, "Over My Dead Body", N.Y. TIMES, Mar. 30, 1996, \& 1, at 24 available

http://uery nytimes com/gst/fullpage.html?res=9A00E6D71539F933A05750C0A960958260 ('s' I think the case is so strong,' Justice Souter said, "that I can tell you the day you see a camera ("I think the case is so strong,' Juste come into our court Antonin Scalia said in October 2005 , We don 't want to become's legal problems."'). Still, the something sick about making entertainment out of real people's legal problems. ".. Stil, the Court has recently made some modest steps toward increased transparency. For example, since October 2006, the Court has released transcripts of oral arguments on the same day that they are heard, followed by audiotapes at the end of each term. See id. at $2 \mathrm{n} .7$.

66 . Values" 60 CORNELL L, REV. 1; 26 (1974).

67. The Quest for a Dignitary Theory, 61 67. Jerry L. Mashaw, 1 .
B.U. L. REV. 885,901 (1981).

B.U.L. REV. 885,901 (1981). 68. See Mark Alan Thurmon, When the Court Divides. Recos (1992); Jay D. Wexler,

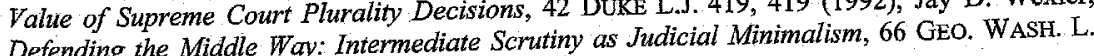


Concerns related to external operation can therefore lead to claims about the nature of the decisions that the Supreme Court should be reaching. Even supporters of a minimalist approach to Supreme Court adjudication ${ }^{69}$ readily acknowledge that "one of [the Supreme Court's] principal functions is to provide guidance for numerous other judges, public officials, and private actors potentially involved with the legal system." minimalism have argued that "narrow" or "shallow" decisions fail to perform this guidance function because they generate uncertainty and instability in other parts of the legal system. ${ }^{11}$ If that claim is true, and if we view that type of uncertainty and instability as problematic, then we may respond by seeking a Supreme Court whose decisions are not only broader but can be implemented predictably and consistently. ${ }^{72}$

The desire for predictability and consistency underlies the distinction that constitutional theorists have noted between constitutional meaning and judicially created constitutional doctrine. ${ }^{73}$ The difficulty in administering abstract constitutional norms has led the Court to develop more easily administered constitutional decision rules. Some of these rules under-

REV. 298, 326 (1998) (" $[T]$ he Court . . has an institutional obligation to give guidance to lower courts, to resolve circuit splits, and to speak to significant constitutional issues."); see also Caperton v. A.T. Massey Coal Co., 129 S. Ct. 2252, 2274 (2009) (Scalia, J. dissenting) ("The principal purpose of this Court's exercise of its certiorari jurisdiction is to clarify the law."); Carolyn Shapiro, The Limits of the Olympian Court: Common Law Judging Versus Error Correction in the Supreme Court, 63 WASH. \& LEE L. REV. 271 (2006) (discussing the Court's failure to provide adequate guidance to the lower courts, 271 (2006) (discussing the Court's procedure to reduce lower court confiusion). Of course prescribed by the Supreme Court by drawing clever distinctions. Only Just Begun: The Impact of Remand Orders Frometinctions. See Michael A. Berch, We've Only Just Begun: The Impact of Remand Orders From Higher to Lower Courts on American urisprudence, 36 ARIZ. ST. L.J. 493, 507-08 (2004).

69. For a defense of Supreme Court minimalism, see ALEXANDER M. BICKEL, THE LEAST DANGEROUS BRANCh: The SUPREME CoURT AT THE BAR OF POLITICS 112 (2d ed. Yale Univ. Press 1986) (1962); SUNSTEIN, supra note 10.

70. Cass R. Sunstein, Problems with Minimalism, 58 STAN. L. REV. 1899, 1911 (2006) 71. See, e.g., Scalia, supra note 11, at 1178-79; Geoffrey Stone, Chief Justice Roberts and the Role of the Supreme Court, The Faculty Blog [of] the Univ. of Chi. Law Sch., (Feb. 2, 2007, 3:32 PM), http://uchicagolaw.typepad.com/faculty/2007/02/chief_justice_r.html\#more ("Whenever the Supreme Court decides a case 'narrowly,' resolving only the particular dispute before it, it leaves the rest of the society and the rest of the legal system in the dark. courts are free to disagree with one another with the of the legal system in the dark..... Lower will vary randomly from state to state and district to district that scope of constitutional rights 72. See, e. Harold It to state and district to district throughout the nation.").

LEE L. REV. 1149, 1151 (1998) (noting that LEE L. REV. 1149, 1151 (1998) (noting that part of the Court's role is to "craft constitutional 73. See Mitchell N Bean administer-not always a simple task") 73. See Mitchell N. Berman, Constitutional Decision Rules, 90 VA. L. REv. 1, 9 (2004)
(distinguishing between "constitutional operative propositions" and "constitutional decision rules"). Not all have agreed that the distinction is meaningful. See, e.g., Daryl J. Levinson,

Rights Essentialism and Remedial Equilibration, 99 ColuM. L. REV. 857.(1999). 
accuracy may be relatively easy to identify. ${ }^{79}$ Only a proper application of the existing rules may be acceptable to governmental actors and the public at large. ${ }^{80}$

But most cases before the Supreme Court do not involve clearly defined rules. The Court has limited resources, and those resources are not well spent in correcting a lower court's misapplication of a clear rule. Accordingly, the Court concentrates on hearing disputes whose resolution requires the creation of a new rule or the clarification of pre-existing rules. ${ }^{81}$ Although cases not controlled by rules do not have clearly correct legal answers, some may have correct moral, cultural, or even political ones. ${ }^{82}$ It stands to reason that a decision that is correct in one of these dimensions is more likely to be acceptable to the public than one that is not. Thus, ideally, the Court should be able not only to correctly apply legal rules, but also to accurately ascertain the correct outcome to a dispute in a more general sense.

\section{HISTORICAL CONSIDERATION OF FACTORS}

Once the institutional goals for the Court have been identified, one is naturally inclined to ask whether, and if so how, Congress weighed these goals in establishing the current size of the Supreme Court at nine members. It turns out that Congress hardly paid any concern to these considerations in establishing the size of the Court at nine.

\section{A. The Act of 1869}

Congress established the current Court of nine members in $1869^{83}$ Although the Court had nine members as early as $1837,{ }^{84}$ Congress had

79. For examples of the Court deciding cases simply to correct a misapplication of clearly established law, see Spears v. United States, 129 S. Ct. 840 (2009) (per curiam); Allen v. Siebert, 552 U.S. 3 (2007) (per curiam).

80. Fallon, supra note 15, at 1794.

81. Frank H. Easterbrook, The Supreme Court, 1983 Term-Foreword: The Court and the Economic System, 98 HARV. L. REV. 4, 5 (1984) ("TT]he Supreme Court possesses discretionary jurisdiction, designed so that the Justices may concentrate on creating rules for the guidance of others.").

82. To be sure, it may be only in the rare case that a question without a correct legal answer has an easily discernable answer along these other lines. Indeed, many commentators view morality, culture and politics as not distinct from, but as part of, constitutional law. See, e.g., RONALD DWORKIN, TAKING RIGHTS SERIOUSLY 149 (1978); Reva B. Siegel, Dead or Alive. Originalism as Popular Constitutionalism in Heller, 122 HARV. L. REV. 191, 234-37 (2008). (1869). reduced the Court's size in 1866 to seven. ${ }^{85}$ So far as the legislative history tells, the 1869 increase back to nine Justices was not based on the conclusion that a court of nine was better than a Court of seven in that it would achieve a better balance of the various factors relevant to Court size. Indeed, nowhere in the debates did anyone state that a larger Court was more likely to decide legal questions correctly, nor did anyone mention considerations of diversity, impartiality, or the ability to provide administrable rules.

The principal reason for the increase was partisan politics. In 1866 Congress had reduced the number of Justices from ten to seven ${ }^{86}$ to deprive Democrat President Andrew Johnson of the opportunity to make appointments to the Supreme Court ${ }^{87}$ Upon the election of Republican Ulysses Grant, the Republican Congress, no longer faced with a hostile president, increased the size to nine. ${ }^{88}$

Partisan politics appears to have played a significant role each of the times that Congress modified the size of the court. Each of the four times that the size of the Court was increased, the same political parties controlled both Congress and the presidency. In 1802, when the Court was increased from five to $\operatorname{six}^{89}$ and in 1807 , when the Court was increased from six to

84. Act of Mar. 3,1837 ; ch. $34, \S 1,5$ Stat. 176,177

85. Act of July 23,1866, ch. $210, \S 1,14$ Stat. $209,209$.

86. Id.

87. STANLEy I. KuTler, JUdicial POWER AND RECONSTRUCTION POLITICS 48 (1968); 3 CHARISS WARREN THE StPREME COURT IN UNITED STATES HISTORY, 1856-1918, at 144-45 CHAR2 (1922) (stating that the Senate passed the bill because it "fear[ed] Sopportunity to make further appointments to the Bench"). Some have argued that the have the opportunity to make further appointments to the Bench"). Some have argued that the reduction was motivated by a desire to avoid evenly decided decisions. But this does not explain why the Court could not be reduced simply to nine--a particulariy conspicuous failure given that the Court already consisted of nine members after the death of Justice Catron and that the original proposal was to reduce the Court only to nine. See CONG. GLOBE, 39th Cong., 1st Sess. 1269 . (1866) (Rep. Wilson) (reporting bill); id. at 3697 (Sen. Trumbull) (moving, without explanation to amend the bill "not to fill the vacancies until the whole number is reduced to seven"). Others have noted that Chief Justice Chase himself sought the reduction to seven to justify an increase in the Justices' salaries. Chase drafted proposed language embodying his plan, and that language formed the basis of the bill passed by the Senate, though without the pay raise. 6 CHARLES FAIRMAN, HISTORY OF THE SUTREME COURT OF THE UNITED STATES: RECONSTRUCTION AND REUNION, 1864-88, PART ONE 167-68 (Paul A. Freund ed., 1971).

88. David Achtenberg, Immunity under 42 U.S.C. \$ 1983: Interpretive Approach and the Search for the Legislative Will, 86 NW. U. L. REV, 497, 549 n.284 (1992) ("Congress's [sic] wearch for the Legislative Will, 8 nine members indicates that it believed that Grant appointees willingness to restore the Court to nine members indicates that it believed that Grant appointe
would be more sympathetic to congressional goals than the existing members of the Court.").

89. The 1801 Act was short lived. Immediately upon taking office, the Democratic Congress repealed Act of Mar. 8, 1802, ch. 8, 2 Stat. 132, thereby restoring the number of Justices to six, though neither Justice Cushing nor any other Justice had left the Court in the interim. 
seven, Jeffersonian Democrats controlled both Congress and the presidency. The 1837 increase from seven to nine Justices occurred under a Jacksonian democratic Congress and president. Republicans controlled.Congress and the presidency when the Court was increased in 1863 from nine to ten and in 1869 when it was increased from seven to nine. By expanding the Court, Congress provided the politically aligned president with an opportunity to fortify the Court with a Justice with similar views. ${ }^{90}$ Thus, for example, the 1837 addition of two Justices was an effort by Jacksonian Democrats to overturn the precedents established under Chief Justice Marshall. ${ }^{91}$ Similarly, the expansion in 1863 to ten Justices afforded Lincoln an opportunity to appoint a Justice sympathetic to the administration's position regarding certain legal issues arising in the Civil War. ${ }^{92}$ Indeed, these exigencies were thought to warrant the increase despite a general sense that the Court was "already too numerous."

90. See, e.g., David P. Currie, The Constitution in Congress: The Most Endangered Branch, 1801-1805, 33 WAKE FoREST L. REV. 219, 229 (1998) (arguing that the Republican Congress enlarged the Court in 1807 to pack the Court); $c f$. Richard H. Pildes \& Daryl J. aration of $P$ arties, not Powers, 119 HaRV. L. REV. 2311,2373 (2006) $60 \%$ when control is divided)

91. Reorganization of the Federal Judiciary: Hearings on S. 1392 Before the S. Comm. on the Judiciary, 75th Cong. 181 (1937) (statement of Edward S. Corwin, Professor, Princeton Univ.). This episode aside, most changes to Court size intended to shift the balance of judicial power from one party to another have not been successful. Rather, successful changes have generally sought to fortify the power of the party already in control.

92. See, e.g., CONG. GLOBE, 40th Cong., 2d Sess. 498 (1868) (Sen. Davis) (complaining that the addition of the tenth Justice was to "make the Supreme Court radical"); DAVID M. SILVER, LinCOLN's SUPREME COURT 84 (1957); The Closing Hours of Congress, N.Y. TIMES, Mar. 4, 1863, at 1 (reporting that the new Justice "of course, adds one to the number which will speedily remove the control of the Supreme Court from the Taney school"). The concern that the Court might hinder the prosecution of the war became particularly heightened when the Court heard the Prize Cases, which examined the legality of the Union blockade of confederate roument. Although the increase had first been proposed on January 6,1863 , by James. Wilson from the Judiciary Committee, no action was taken on the bill for over a month. It was only in he wake of the argument in the Prize cases that the Senate took up the measure, passing it on February 26 without debate. CONG. GLOBE, 37th Cong., 3d Sess. 1300-01 (1863). The Hous followed suit a few days later, also without debate. $I d$. at 1484 . Although some have argued that the creation of the tenth Justice was in response to the narrow margin in the Prize Cases, see, for Cxample, HAROLD M. HYMAN \& WTLLAM M. WTCEK, EQUAL JUSTYCE UNDER LA CONSTITUTIONAL DEVELOPMENT, 1835-1875, at 363 (1982), the croation of the tenth Justice pre-dated that decision.

93. CONG. GLOBE; 29 th Cong., 1 st Sess. 262 (1846). According to the New York Evening Post, the "generally favored". solution was to relieve the Court from circuit duty and reduc their number to six, 2 WARREN, THE SUPREME COURT IN UNTTED STATES HISTORY, 1821-1855, at $541 \mathrm{n} .1$ (1923), and in that spirit, some legislators advocated reducing the Court to eight seven, or six, see ConG. GloBe, 29th Cong., 1st. Sess. 297 (Sen. Bayard) (indicating his
By contrast, each of the two times that Congress reduced the size of the Court, the president was of a different political party than Congress, and Court, the president was of a difte president was running high. ${ }^{94}$ The 1801 reduction of the Court was to deprive the incoming Republican president Thomas Jefferson of an opportunity to appoint a Justice ${ }^{95}$ - a prospect that seemed imminent because of the ill health of Justice Cushing ${ }^{96}$-and, as noted above, the 1866 reduction was to deprive Johnson of an appointment to an already open vacancy on the Court. ${ }^{97}$

Another reason for the increase in 1869 to nine Justices was to solve a problem with circuit riding. Beginning with the Judiciary Act of 1789 , Congress divided the country into judicial circuits, and instead of appointing judges for those circuits, required the Justices to travel to the various circuits to hear cases. ${ }^{98}$ Despite constant complaints about the circuit-riding system, ${ }^{99}$ Congress refused to abandon the scheme, with the exception of a brief period during the early $1800 \mathrm{~s}^{100}$

preference for a six or eight member court); id. at 261-62 (1846) (Sen. Johnson) (advocating reduction to seven Justices). Even legislators who sought to alleviate the circnit dockets by adding Justices admitted that the Court was "too large already." CONG. GLOBE, 33d Cong., 2d Sess. 299 (1855) (Sen. Badger).

94. In 1801 the Federalists reduced the Court from six to five upon losing the 1800 94. In 1801, the Federallsts reduced the Court from sin to the tepublican Congress elections. Act of reduced the Court from ten to seven upon the ascension of Democratic President Johnson. Act of July 23,1866 , ch. $210, \S 1,14$ Stat: $209,209$.

95. See Kathryn Turner, Federalist Policy and the Judiciary Act of 1801, 22 WM. \& MARY Q. 3, 20-21 (1965). On the other hand, Democrats sought to assure appointments for incoming Q See 3 S. JOURNAL 121-22 (1801)

96. Reorganization of the Federal Judiciary: Hearings on S. 1392 Before the S. Comm. on the Judiciary, 75th Cong. 40 (1937) (statement of Robert H. Jackson, Assistant U.S. Attorney Gen.).

97. Similar concerns have motivated opposition to expansion. For example, opponents to an expansion of the Court to ten in the 1820 s criticized the proposal on the grounds that the expansion would permit President Adams to provide patronage to gain favor after his dubious (Wection 2 REG DER 488 (1826) (Woodbury); id. at 943 (Rep. Magnum); 2 WARREN, supra

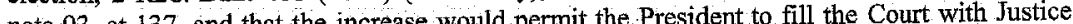
note 93, at 137, and that (herer) likew would fill the new vacancies with pro-slavery Justices. 2 WARREN, supra note 93 , at 541 .

98. Act of Sept. 24,1789 , ch. $20, \S 4,1$ Stat $73,74-75$.

99. The Justices often complained of the physical difficulties and dangers of circuit riding. is as being forced to "lead, twice in a year, the life of WO " post boy. 4DOC William Cushing's wife referred to "taveling machin," herself and her husband as "traveling machines." Id. at 134; see generally Joshua Glick, Comment, On the Road: The Supreme Court and the History of Circuit Riding, 24 CARDOZO-L. REV. 1753, 1765-66 (2003) (discussing difficulties of circuit riding). Attorney General Randolph criticized circuit riding on the grounds that the arduous task would lead to terms "too 
Although Congress originally designated two Justices to each circuit, ${ }^{101}$ expansion of the country led Congress to designate only one Justice to each circuit, thereby tying the number of circuits to the number of Justices. ${ }^{102}$ But that changed when Congress reduced the Court to seven Justices in 1866. The reduction was to be accomplished by not filling the seats of the first two Justices to leave the Court; since there were still nine Justices on the bench at the time of the enactment, the act left the number of circuits at nine. ${ }^{103}$ This arrangement posed a problem, however, when, with the death of Justice Wayne in 1867, the number of Justices fell to eight while the number of circuits remained at nine ${ }^{104}$ This left one of the circuits without a Justice to preside over it. Senator Lyman Trumbull, the sponsor and principal advocate of the bill to increase the Court's membership to nine, ${ }^{105}$ justified the bill on the ground that restoring the Court's membership to nine would realign the Justices with the circuits. ${ }^{106}$

It was nothing new that circuit riding played such a significant role in the 1869 expansion. Each expansion of the Court resulted from the addition of

short for any important proficiency," and that it created a conflict of interest by requiring Justices who heard a case on circuit to rehear it at the Supreme Court. EDMUND RANDOLPH, JUDICIARY SYSTEM, H.R. MISC. DOC. NO. 1-17, at 24 (1790). Interestingly, although both Randolph and the Justices sought the abolition of circuit riding, neither requested the appointment of more Justices to alleviate the burden.

100. Circuit riding was abolished in 1801. See Act of Feb. 13, 1801, ch. 4, 2 Stat. 89. It was reinstituted in 1802. See Act of March $8,1802, \mathrm{ch} .8, \& 1,2$ Stat. 132, 132. Although Congress began to ease circuit riding duties as early as 1844 , see Act of June 17, 1844, ch. 96, $\S 2,5$ Stat. 676,676 , circuit riding was not officially abolished until 1911. See Judicial Code of $1911, \mathrm{ch}$. 231,36 Stat. 1087.

101. $\$ 4,1$ Stat. at $74-75$.

102. Act of Mar. 2, 1793, ch. 22, § 1, 1 Stat. 333, 333

103. Act of July 23,1866 , ch. $210, \& 1,14$ Stat. 209, 209.

104. Foreseeing this problem in 1866 , Sen. Trumbull stated that when a vacancy occurred that was not to be filled, Congress could reduce the number of circuits accordingly. See CONG. GLOBE, 39th Cong., 1st Sess. 3697. Congress failed, however, to do so.

105. CONG. GLOBE, 41 st Cong., 1st Sess. 29, 62 (1869).

106. Id. at 208; see also id. at 210 (Sen. Stewart) (praising the bill because it "provides that the Supreme Court shall consist of nine judges, the same number of judges that we have circuits" and describing the bill as designed solely for "giving to the Supreme Court a sufficient number of judges to correspond with the circuits as we now have them."). Discussing similar legislation in the previous term, Trumbull had argued that the Court should be no larger than nine for institutional reasons. CoNG. GLOBE, 40th Cong., 3d Sess. 813 (1869) (reporting bill). nine for institutional reasons. CONG. GLOBE, 40th Cong., 3d Sess. 813 (1869) (reporting bill).
Nine, Trumbull explained, was not only the minimum number of Justices necessary to have sufficient Justices to ride the nine circuits, but it was also the maximum size for an en banc Court. A more numerous court, he contended, would be "more like a legislative body; the sense of personal responsibility is not felt, and each judge will not investigate for himself each case; and in fact it becomes impossible to do it when the number of cases is so large as it is in the United States." CONG. GLOBE, 40th Cong., 3d Sess. 1484 (Sen. Trumbull). new circuits, and corresponding Justices, for newly added states. ${ }^{107}$ Thus, the 1807 creation of a seventh circuit and a corresponding seventh Justice ${ }^{108}$ resulted from the clamoring by the recently admitted states of Kentucky, Ohio, and Tennessee to be included in the circuit system. ${ }^{109}$ Similarly, the need to include the "States of the West and Southwest" in the circuit system led to the increase in 1837 to nine circuits and nine Justices. ${ }^{110}$ And the addition of Oregon and California prompted the creation of the tenth Justice in 1863 to represent a tenth circuit: ${ }^{.11}$

Although politics and circuit riding were the principal reasons for the increase of 1869 , this does not mean that Congress set the size of the Court without any concern for institutional benefits. For one thing, circuit riding itself promoted diversity. Early on, the president adopted an informal practice of appointing Justices who practiced in the circuit in which he would ride. ${ }^{112}$ Doing so conveyed to the people in each circuit that their regional interests were "represented" on the Supreme Court. ${ }^{113}$ It also increased informational diversity by ensuring that one Justice could inform the others of the distinct legal problems relating to cases arising out of his circuit $^{114}$-an especially important feature in diversity-jurisdiction cases,

107. Thus, when Congress abolished circuit riding in 1801 , and consequently no longe 107. needed to the the mile maintining six eircuits. Act of Feb. 13, 1801, ch. 4, \& 3, 2 Stat. 89, 89.

108. Act of Feb. 24,1807 , ch. $16, \S 5,2$ Stat. 421,421 .

109. See Felix FrankfitiRTER \& JAMES M. LANDIS, THe Business of THE SUPREME COURT: A STUDY IN THE FEDERAL JUDICIAL SYSTEM 33 (1928) (recounting history).

110. Act of Mar. 3, 1837, ch. 34, \& 1, 5 Stat. 176. According to Charles Warren, Congres had recognized much earlier that it needed to provide relief for the judicial system in the sou sounwe bouthwest had crowded conditions of the inferior Federe necessary and its refusal a scandalous denial of justice become such as to make relief absolutely necessary and its refusal a

111. Act of Mar. 3,1863 , ch. $100, \S 1,12$ Stat. 794 . Congress had created a tenth circuit embracing California in 1855, Act of Mar. 2,1855 , ch. $142, \$ 1,10$ Stat. 631 , but the Act did not provide for a tenth Justice, in part because the transportation then available did not permit a rot pre supreme Court in the same year. CONG. The horizon with GLOBE, 33 Cong the founding of the Union Pacific Railroad. Reorganizalion of the Federal Julding on S. 1392 Before the S. Comm. on the Judiciary, 75th Cong. 763 (1937) Thereinafter Reorganization Hearings] (testimony of Erwin Griswold, Professor, Harvard University Law School).

112. See A.L: TODD, JUSTICE ON TRIAL: The CASE OF LOUIS D. BRANDEIS 137 (1993).

113. Id.

113. Id.

114. This concen was nost sustices from 1863 because of the perception the the the east were unfamiliar. See Robert McCloskey, Stephen J. Field, in 2 THE JUSTCES OF THE UNITED STATES SUPREME COURT 1789-1978: THERR LIVES AND MAJOR OPINIONS 1069, 1073 (Leon Friedman \& Fred L. Israel eds., 1969). 
which required the Justices to apply state law. Although these notions were not mentioned during the 1869 debate, ${ }^{115}$ the decision in 1869 to maintain the system of one Justice from each geographic circuit ensured that those benefits would not be lost. ${ }^{116}$

One institutional concern that arose briefly during the 1869 debate was expediency. Senator Trumbull maintained that the increase would relieve pressure on the Court, which was "overloaded with business."117 But that seems more a pretextual justification than an actual reason. The Court had faced an ever-increasing backlog during the mid-1800s, yet Congress had not seen it necessary to expand the Court to deal with this crisis. ${ }^{18}$ To the contrary, Congress reduced the size of the Court in 1866, with Senator Trumbull himself sponsoring the bill. ${ }^{119}$

Another institutional point came from Senator Casserly, who, in criticizing a competing proposal to increase the Court to eighteen, ${ }^{120}$ argued that "[n]ine judges is probably very near the just medium between a court too small and a court too large," and that "[i]n a court of eighteen the business of decision[s] must resolve itself into a mere contention of votes; not a discussion of principles nor a balancing of reasons and analogies, but into a mere contention of votes." 121 Senator Casserly's analysis is not particularly sophisticated; it rests on the assumption that smaller deliberating bodies are more likely to reach correct decisions than a larger voting body - an assumption that is not necessarily warranted, as explained in Part III. ${ }^{122}$ Still, Senator Casserly's point, and the point raised by Senator Trumbull, ${ }^{123}$ are rare exceptions in a record otherwise devoid of evidence of Congressmen thinking about the Court's size in institutional terms.

Of course, other congressmen might have privately weighed these considerations or simply not recorded them in the Congressional Record. But even if the 1869 Congress had made a functional determination in favor of a nine member court, that would not necessarily mean that nine is the

115 CONG. GLOBE, 41st Cong., 1st Sess. 207-19 (1869)

116 Id. at 219 ; see Judiciary Act of 1869 , ch. 22,16 Stat. 44.

117. CONG. GLOBE, 41st Cong., 1st Sess. 208 (1869) (statement of Sen. Trumbull).

118. See, e.g., FRANKFURTER \& LANDIS, supra note 109, at 69-70 (attributing increasing dockets to the business boom beginning in the $1840 \mathrm{~s}$ and the addition of more states).

119. CONG. GLOBE, 39th Cong., 1st Sess. 3697 (1866) (statement of Sen. Trumbull) (moving to amend the bill "not to fill the vacancies until the whole number is reduced to seven").

120. Sen. Williams had proposed to expand the bench to eighteen Justices, with nine sitting in Washington and the others riding circuit; with a turnover of three Justices per year. CONG. GLOBE, 41st Cong., 1st Sess. 209 (1869) (statement of Sen. Williams).

121. CONG. GLOBE, 41st Cong.; 1st Sess. 214 (1869) (statement of Sen. Casserly)

122. See infra Part III

123. See supra note 115 and accompanying text.

appropriate membership for today's court, which arguably performs a much different function. For example, the Court no longer sits to resolve disputes. Since the Court gained discretionary jurisdiction in 1925 , $^{124}$ the Court's principal function is to provide guidance to the lower courts. ${ }^{125}$ Given the change in the Court's institutional function between 1869 and today, any weighing of institutional qualities in 1869 is unlikely to be well tailored to today's needs.

\section{B. Roosevelt's Failed Expansion Effort}

The only serious effort to change the size of the Court after 1869 was Franklin Roosevelt's Court-packing plan in 1937. Roosevelt's proposal, which would add a new member for each Justice over the age of seventy up to a total membership of fifteen, ${ }^{126}$ was not designed to create an ideally sized Court. No one claimed that fifteen was the optimal size for the Court; sized Come of those supporting the increase stated that it would indeed, some of the Court's efficiency. ${ }^{127}$ Rather, Roosevelt's goal was to undermine the Court from striking down New Deal legislation. ${ }^{128}$ During the prevent the Court from striking down New Deal legislation. 1930s, the Court had struck down several key pieces of legislation, and the addition of new Justices was thought to assure that future New Deal legislation would be upheld. ${ }^{129}$ As is well known, the plan failed when the Court reversed course, issuing two 5-4 decisions upholding critical New Deal legislation, ${ }^{130}$ and Justice Van Devanter, a perennial opponent of New Deal legislation, retired, presenting Roosevelt the opportunity to create a sympathetic majority on the Court without the

124. Judiciary Act of 1925 , ch. 229,43 Stat. 936

125. See Easterbrook, supra note 81 , at 5 .

126. The proposal called for a new appointment when a Justice who had served ten year did not retire within six months of turning seventy. See PRESIDENT'S MESSAGE TO CONG. did not rire DOC. NO. $75-142$, at 9 (1937).

(statement of Erwin N 127. See, e.g., Reorganization Hearings, supra nool ("[N]0 one .... really [thought] that Griswold, Professor, Harvard University Law School) (Ne Court's work.").

128. William $\mathrm{E}$ Leuchtenburg, The Origins of Franklin D. Roosevelt's "Court-Packing" 128. William E. Leuchtenburg, The Origins of Franklin. Rehnquist, Judicial Independence, Plan, 1966 SUP. CT. RE. 347 (2004) ("The true reason for the plan, of course, was to enable the

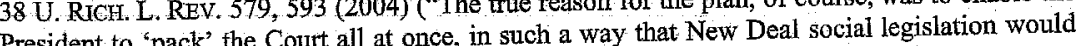
President to "pack' the Co

no longer be threatened.").

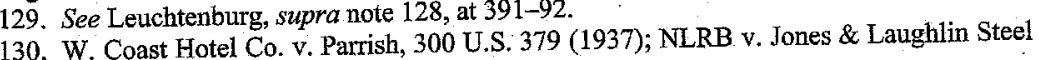
Co., 301 U.S. 1 (1937). 
Court-packing plan. ${ }^{131}$. The plan's failure reflected the sense that the increase was no longer necessary once the Court's threat to the New Deal subsided.

To be sure, Roosevelt, aware of the impropriety of tinkering with the Court merely to achieve political results, did argue that the plan was for the benefit of the Court. He claimed that the Court had fallen behind in its work because the older Justices were unable to carry their load and that the addition of new, younger Justices would cure the problem. ${ }^{132}$ That the stated justification was pretextual became evident when Chief Justice Hughes wrote a letter to Senator Wheeler, who shared it with the rest of the Senate, providing statistics demonstrating that the Court was up to date on its work. ${ }^{133}$ Far from making the Court more efficient, Hughes's view was that the increase would render the Court unmanageable. ${ }^{134}$ As Hughes put it, increasing the number of Justices would mean "more judges to hear, more judges to confer, more judges to discuss, more judges to be convinced and to decide[,]"135 and it would "make the Court a convention instead of a small body of experts," 136 which would "confuse counsel within the Court, and ... cloud the work of the Court and deteriorate and degenerate it."137

The rejection of the proposed increase to fifteen did not entail an endorsement of nine as the ideal size of the Court, however. Indeed, in his letter criticizing Roosevelt's planned expansion, Chief Justice Hughes suggested that a five-member Court would be best, ${ }^{138}$ but this prompted no action from Congress.

131. William E. Leuchtenburg, The Supreme Court Reborn: The Constitutional REVOLUTION IN THE AGE OF ROOSEVELT 154 (1995).

132. 2 BRuCE ACKeRman, We tHE People: TRAnSformations 318 (1998); Relinquist, supra note 128 , at 593 .

133. Letter from Charles E. Hughes, Chief Justice, U.S. Supreme Court, to Burton K. Wheeler, U.S. Senator (Mar. 21, 1937), in Reorganization of the Federal Judiciary: Hearings on S. 1392 Before the S. Comm. on the Judiciary, 75th Cong. 488 [hereinafter Hughes' Letter] (testimony of Sen. Wheeler reading a Mar. 21, 1937 letter from Chief Justice Hughes).

134. Id. at 491. Even after Hughes' refutation, some proponents of the bill still argued that the plan was necessary to alleviate the Court's workload. Arthur Corwin, for example, argued that the Court should be increased, but that, because of manageability concerns, the court should be divided into panels. See, e.g., Reorganization Hearings, supra note 111, at 216-17 (testimony of Edward S. Corwin, Professor of Jurisprudence, Princeton University).

135. Hughes' Letter, supra note 133, at 491.

1362 JoAn BiskUPIC \& Elder WITT, GUIDE TO THE U.S. SuPREME COURT 817 (3d ed. 1997).

137 Id:

138. Id.

\section{COURT SIZE AND FUNCTIONALITY}

We began by surveying a variety of institutional characteristics we might expect to see in an acceptable and well-functioning Supreme Court. We then reviewed the historical evidence, which suggests that consideration of these characteristics - or indeed, of any set of functional characteristicswas minimal to non-existent in the debates surrounding the size of the Supreme Court. Here, we return to our initial discussion and develop an account, based largely on social science studies of group performance, of how size may affect whether and how the Court will reflect the identified institutional features in practice. Before proceeding further, we should emphasize that what follows is neither exhaustive nor definitive; each of the issues discussed here is complex, and the interaction between them only magnifies that complexity. ${ }^{139}$ Rather, our goal is relatively modest: to sketch the various ways that size may affect Court performance and to suggest that size might reasonably play a role both in understanding the operations of the current Court and in thinking about how those operations might be improved.

\section{A. Impartiality and Independence}

Impartiality and independence are critical features of the Supreme Court. The size of the Supreme Court has a strong potential to affect the attainment of these goals.

\section{Impartiality}

The basic concept of impartiality is that a judge cannot have an actual or perceived bias affecting his decision in the case. ${ }^{140}$ At the same time, judges unavoidably come to the bench with a host of conscious and unconscious biases-stemming from their upbringing, education, experiences, and personal characteristics such as race and gender ${ }^{141}$ - each of which has the

139. See Peter Kollock, Social Dilemmas: The Anatomy of Cooperation, 24 ANN. REv. SOC. 183 . of the multiplicity of factors that contribute to group performance).

140. See supra text accompanying notes $23-24$.

141. See Debra Lyn Bassett, Recusal and the Supreme Court, 56 HASTINGs L.J. 657, 66667 (2005) (gathering literature); Richard A. Posner, The Role of the Judge in the Twenty-First: Century, 86 B.U. L. REV. 1049, 1060 (2006) (hypothesizing that preferences "are a product of upbringing education, salient life experiences, and personal characteristics (which may detringing, education, sach as race, sex, and ethnicity; and also of temperament, which 
potential to affect the outcome of a particular case. ${ }^{142}$ An aggressive limitation on the presence of bias therefore threatens the ability of the judiciary to function. For that reason, and also because some forms of bias are particularly hard to identify and assess, only certain biases are deemed sufficient to result in recusal. ${ }^{143}$ Although permissible biases do not require recusal, they still may result in prejudice. Increasing the Court's size may help to reduce the impact of these biases. To the extent that enlargement facilitates diversification of the biases on the Court, a larger Court will decrease the impact of each Justice's bias simply because each vote becomes less significant to determining the outcome of the case. Where one judge hears a case in trial court, for example, his biases alone control the outcome of a case. By contrast, on a court with three members, no one judge's biases can control the outcome of a case; there must be agreement between at least two members. More than that, the diversification of viewpoints through expansion of the Court may reduce the strength of an individual's bias. The expression of a differing view can lead those holding a particular bias to reassess their position and reduces the possibilities for group polarization and informational cascades. ${ }^{144}$

Beyond reducing the impact of a single bias, diversification through enlargement also reduces the potential for the perceived bias. ${ }^{145}$ Members of a minority group not represented on the Court may perceive institutional bias if they conclude that the Court is predisposed against them or does not understand their plight. ${ }^{146}$. That perceived bias is likely both too narrow and too broad-too narrow because one does not need to be a member of a group to understand the claims of that group, and too broad because a

shapes not only values but also dispositions, such as timidity and boldness, that influence a judge's response to cases").

142. See Judging the Judges, supra note 19; see also Gene R. Nichol, Jr., Standing for Privilege: The Failure of Injury Analysis, 82 B.U. L. REV. 301 (2002) (arguing that personal biases impact judicial decisions regarding justiciability).

143. Bassett, supra note 141, at 671 ("If certain biases are indeed unconscious, perhaps no recusal provision can reach them, which leaves the question how to reach as many forms of bias as possible."). Limiting recusals has particular importance on the Supreme Court, because there are no substitutes for recused Justices. Each recusal therefore not only increases the chances that the Court cannot hear a case because of a lack of a quorum, but also may actually increase the effect of biases held by other Justices.

144. E.g., Cass R. Sunstein, Group Judgments: Statistical Means, Deliberation, and Information Markets, 80 N.Y.U. L. REV. 962, 1028-31 (2005).

145. Perceived bias is likely to be particularly acute among members of a minority group not represented on the Court, because that group might think that the Court is predisposed against them or does not understand their plight. See generally Judging the Judges; supra note 19 , at 98-99 (contending that "judicial impartiality mandate is violated by the persistent presence of an all-white bench in jurisdictions with significant minority populations").

146. Judging the Judges, supra note 19 , at 99. member of a group need not share the views of that group. Nevertheless, it is the perception's existence, not its accuracy, that matters. To the extent that enlargement results in the addition of a member of a minority group, it reduces this perceived bias. ${ }^{147}$

Everything so far suggests that expansion can only benefit impartiality, but that is not so. Because each individual carries his own set of biases, enlarging a group also increases the probability of introducing new biases that adversely affect decision-making. The monitoring costs of detecting those biases will increase as the pool of potential biases increases. Enlarging the Court may also hinder deliberation, ${ }^{148}$ resulting in less informed decisions. Moreover, on a larger court, each Justice may feel less obliged to reconsider his own biases because of a belief that his biases will have less impact given the larger Court:

Expansion also presents the possibility of strengthening the effect of a bias. If a newly added member holds the same bias held by another on the Court the shared bias might lead the Justice who might otherwise question or reassess his position when confronted with unified opposition not to do so. ${ }^{149}$ Indeed, shared biases may actually enhance the strength of a bias through group polarization, especially if no other Justice holds a strongly opposing view. In short, expansion reduces the threat of impartiality only if the newly added members do not introduce new biases and do not amplify biases already present on the Court.

\section{Judicial Independence}

Increasing the size of the Court also supplements Article III's measures to insulate individual Justices from pressures from interest groups and government officials. Article III provides strong protections for and government officials. Article III provides strong security. ${ }^{150}$ The only means the Constitution provides for holding individual Justices accountable

147. See Racial Diversity, supra note 15 , at 411 ("[D]iversity on the bench ... encourages 147. See Racia Daves do not dominate judicial judicial impartiality, b

ecision-making.")

148. See, e.g., L. L. Cummings, George P. Huber \& Eugene Arendt, Effects of Size and Spatial Arrangements on Group Decision Making, 17 ACAD. MGMT. J. 460, 461 (1974) ("[A]s group size increases [from two to twelve members], average member participation declines.").

149. See Richard O. Lempert, Uncovering "Nondiscernible" Differences: Empirical Research and the Jury-Size Cases, 73 Mich. L. REv, 643, 690 (1975)

150. U.S. CONST. art. III, \&1. 
is impeachment, which was rendered essentially a dead letter soon after the Constitution's adoption because of concerns about judicial independence. ${ }^{151}$

Despite the unavailability of effective means to pressure individual Justices formally, there are more informal means, like the press. ${ }^{152}$ But the ability to use the press or impeachment effectively becomes more costly as the size of the Court increases. Exerting pressure through impeachment or the size of the Court increases. Ex-the price of gathering information, the loss of time that could be spent on other matters, and political capital. Of course, the mere threat of resorting to those devices may be sufficient to influence behavior. ${ }^{153}$ But that threat loses credibility when the costs to carry it through are prohibitively high, and a larger Court will drive up costs because more Justices will need to be influenced. Exerting pressure on the Court is most worthwhile when the pressure affects the Court's decisionsthat is, when it results in a majority of the Court supporting the interest group's agenda. As the Court grows larger, the average cost of securing a majority increases as the number of Justices that must be pressured rises. ${ }^{154}$ If two thirds of a Court of nine disagrees with a particular position, changing the result requires influencing two Justices; increasing the Court to fifteen increases the number who must be swayed to three.

To be sure, an increase in the size of the court will not always increase the cost of exerting pressure. Regardless of size, there will always be cases where only one Justice must be influenced to change the outcome of the

151. WILIIAM H: REHNQUIST, GRAND INQUESTS: THE HISTORIC IMPEACHMENTS OF JUSTICE 151. WILA AND PREST 11819 (1992).

152. Harold Baer, Jr., Interview: A Unique Perspective on Judicial Independence, 25 152. Harold Baer, Jr., Interview: A that public criticism has a "chilling effect on judicial independence"). Ferejohn and Kramer note that another way in which politicians may exert pressure on individuals is through the promise of a promotion to the Supreme Court. Ferejohn \& Kramer, supra note 14, at 981 . That concern of course has no bearing on our project, because we are coremed only with those already on the Supreme Court.

153. 153. Justico improper financial dealings. See DAVID W. NEUBAUER \& STEPHEN S. MEN 507 (3d ed. 2004)

PROCESS: LAW, COURTS, AND POLITICS IN THE UNITED STATES 507 (3d ed. 2004).

154. Cf. Jonathan R. Macey, Transaction Costs and the Normative Elements of the Public Choice Model: An Application to Constitutional Theory, 74 VA. L. REV. 471, 495 (1988) (arguing the costs for interest groups to implement their agenda). This branches ef gove Justice does not equally impose identical pressure assumes that the exertion of pressume on though it is important to on another Justice. Experience suggests that this is a far assict recognize that the exertion of pressure on one Justice probably has some effect on other Justices. case..$^{155}$ The point is that, on average, the cost of influencing the outcome of a case will be higher on a larger court.

This all points in favor of increasing the size of the Court because doing so enhances the protections for individual Justices from external forces. But protecting Justices from external influence is not an unmitigated good; complete protection strips the Justices of any accountability. For this reason, although providing virtually no means to influence an individual Justice, the Constitution provides several means by which political actors can influence the Court as an institution. ${ }^{156}$

One example is the appointments power, which provides the President, and to a lesser degree the Senate, the opportunity to reshape the Court. ${ }^{157}$ Altering the size of the Court would not necessarily undermine this power; to the contrary, the ability to alter the size of the Court may give an opportunity to exert influence through the appointment power. Expanding the Court allows the political branches to change the bench's leanings more quickly through appointments. ${ }^{158}$. Expansion would also tend to increase turnover, which would mean the appointments process occurs more oftenthough it may not necessarily translate into greater direct control over the Court, since each appointment carries less weight as the size of the Court increases.

Other devices for control over the judiciary include Congress's control of the judicial budget, jurisdiction, and procedure in the federal courts, as well as the Executive's power to refuse to enforce the Court's decrees. ${ }^{159}$

155. This is so whether the court has an even or odd number of Justices. On an odd number court there an be situations where those in the majority exceed those in the dissent by only one cote outcome. Likewise, on an even vote, and the switch of one vote will accordingly change the outcome. number court, only one vote change is nece

court into a reversal by a margin of two votes.

156. Ferejohn \& Kramer, supra note 14, at 981 ("If relatively few devices are available to control individual judges, a great many more can be directed at the institution of the judiciary as a whole."). Not everyone has been in favor of reducing individual accountability of the Justices. In the debates establishing the Supreme Court, Senator Maclay argued against a large Court on The gith

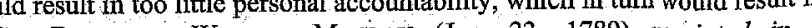
inferior decisions. See DIARY OF WILLIAM MACLAY (Jun. 23, 1789) reprinted in 4 DOCUMENTARY HISTORY OF THE FIRST FEDERAL CONGRESS OF THE UNTTED STATES OF AMERICA: 4 MARCH 1789-3 MARCH 1791, at 413-14 [hereinafter MACLAY's DIARY], available at http://www.constitution.org/ac/maclay/joumal03.txt (stating that "numbers rather lessened responsibility" and unless the judges "were all eminent, tended to obscure the decisions").

157. U.S CONST art II \& 2 (the President "shall nominate, and by and with the Advice and Consent of the Senate, shall appoint ... Judges of the supreme Court").

158. Roosevelt's court packing plan is one example. For examples on the lower courts, see DEBORAH J. BARROW ET AL., THE FEDERAL Judiciary and INSTITUTIONAL CHANGE 93-94 (1996)

159. Ferejohn \& Kramer, supra note 14, at 976-77. The extent of some of these powers bas been subject to much debate. See RICHARD H. FALLON ET AL., HART \& WECHSLER's THE 
Increasing the size of the Court does not significantly undermine these means for checking the Court, as the processes through which Congress or the Executive exercises those powers do not change with the number of Justices. ${ }^{160}$ One might argue that enlarging the Court could increase the monitoring costs to determine when to use these devices against the Court, because a larger Court will produce more decisions in the same amount of time. But it is far from certain that a larger Court would produce more decisions. Although a larger Court might have that capacity to the extent that more Justices are available to write opinions for the Court, that gain in productivity may well be offset by the time lost to the additional negotiations that come with a larger Court.

\section{B. Diversity, Representation, and Collegiality}

To review, proponents of diversity on the Supreme Court have claimed at least two types of benefits. ${ }^{161}$ One is based on inclusion. Nominating an African-American Justice, for example, expresses the message to other African-Americans that they are full members of the political system generally, or of the judicial system more specifically. The inclusion of diverse members will increase the likelihood that the decisions reached by the Court will be accepted by the public and by the minority group in particular. This claim includes no assertion that decisions will be objectively superior as a result of the Court's diversity, but only that institutional diversity will promote legitimacy and acceptance. The other benefit springing from diversity is that it adds functional superiority: the presence of intellectual and informational diversity on the Court will improve decisional outcomes.

Institutional size may affect the ability of the Court to produce these benefits. ${ }^{162}$ To begin, size may influence the extent to which diverse

FEDERAL COURTS AND THE FEDERAL SYSTEM 337-42 (5th ed. 2003) (jurisdiction stripping) Dale Carpenter, Judicial Supremacy and Its Discontents, 20 CONST. COMMENT. 405, 421-424 (2003) (questioning executive refusal to enforce a judicial order); see also Tony Mauro, The Chief and Us: Chief Justice Williom Rehrquist the News Media and the Need for Dialogive

Between Judges and Journalists, 56 STRACuse L. Rev. 407,416 n 34 (2006) (appropriations).

160. There is a chance that the size of the Court may affect the political costs of exercising these powers. The public may perceive that a decision rendered by a larger Court carries a stronger mandate and therefore oppose a negative response by Congress or the Executive. But other factors, such as whether the decision was unanimous, may well have more significant impact.

161. See supra Part I.B.

162. This section takes as its starting point the idea that inclusion, acceptance, and representation are desirable ends and then explores the role of size in producing those ends. We acknowledge, however, that this is not an uncontested point. See, e.g., WALTER BENN members are present on the Court. The inclusion and legitimacy arguments for diversity require only the factual presence of diverse members. Larger groups provide greater opportunity for diversity, ${ }^{163}$ and are therefore more likely to meet a presence requirement. Additionally, minorities may be more likely to be selected for new seats than for pre-existing ones, because there may be an expectation that a vacancy in a pre-existing seat should be filled with a Justice similar to the one who has departed. ${ }^{164}$ As a result, adding to the existing size of the Court may be particularly likely to result in greater diversity-though the importance attached to inclusion may simultaneously decline as size expands and each Justice takes on a less prominent role.

A more complex question is how size interacts with the functional benefit of informational diversity. To obtain this benefit, the mere presence of diverse members is not sufficient. Instead, the diverse members must contribute to the process, and those contributions must improve the Court's decision-making. Increasing the size of the Court may permit greater diversity of information and the involvement of a larger range of views and perspectives. But there is a danger that expanding the Court too much perspectives. But there is a danger that explional conflict. ${ }^{165}$ Either of would diminish participation or increase emotional conflict. Either of these results could dampen or erase the beneficial effect of increased diversity.

MiChaELS, THE TROUBLE WTH DIVERSITY: How WE LEARNED TO LOVE IDENTTTY AND IGNORE INEQUALITY (2006).

163. See, e.g., Richard I Moreland, John M. Levine \& Melissa L. Wingert, Creating the Ideal Group: Composition Effects at Work, in UNDERSTANDING GROUP BEHAVIOR: SMALL GROUP PROCESSES AND INTERPERSONAL RELATIONS 11, 13 (Erich Witte \& James H. Davis eds. 1996) ("Another advantage of larger groups is that they tend to be more diverse."); Lempert 1996) ("Another advantage of larger groups is thallowed this general pattern. See Rorie Spill supra note 148, at 673. The lowe Ninth Circuit and Its Sisters, 48 ARuz. L. (ne pre-split Fifth Circuit "diversified REV. 247,256 (2006) (noting that the Ninth
earlier and more broadly than their sisters").

164 See Solberg supra note 163 , at 251 (explaining that, "when filling a new seat, the
arlier and more broadly tha their sisters"). ddition of a woman or minority will not come at the "expense' of the majority"). This ma include broader political diversity as well. BARROW ET AL., supra note 158, at 75-76 (arguing that rresidents are more willing to reach across the aisle when filling new seats)

165. Se Robert M. Bray, Norbert L. Kerr \& Robert S. Atkin, Effects of Group Size, Terom Permance and Member Reactions, 36 J. PERSONALITY Problem Difficulty, and Sex on Group Performance and Mer \& SoC PSYCHOL. 1224, 1233-34-(1978) (A] group size increases, the number ${ }^{\prime}$ eilly group members increases ....."); Katherine Y. Williams \&. Charles A. O'Reilly, II Demography and Diversity in Organizations: A Review of 40 Years of Research, 20 REs. ORganizational BeHAV.: AN ANN. SERIES ANALYTICAl ESSAYS AND CRITICAL REVS. 77, 12 (Barry M Staw \& L.L. Cummings eds., 1998) (suggesting that group heterogeneity has the potential to result in better decisions but also increased emotional conflict). 
Before turning to these dangers, we must first sketch the dynamics of diversity. ${ }^{166}$ There is ample evidence from the literature on organizational behavior that the presence of informational diversity can enhance group performance. ${ }^{167}$. The precise nature of this enhancement depends on the nature of the task being performed. For problems with a clear and easily recognizable answer, a more diverse group can increase the probability that one member will possess the knowledge necessary to formulate the correct answer. ${ }^{168}$ While the occasional Supreme Court case may fit this description, most will lack the necessary predicate of a definite answer. ${ }^{169}$ More likely in the context of the Supreme Court is that diversity will prompt more thorough and more productive deliberation, which can enhance the solution of complex problems without a clear answer. ${ }^{170}$ Deliberative enhancement occurs because diverse members introduce into the deliberative process new informational perspectives that can improve outcomes in various ways. As an initial matter, a larger number of informational perspectives translates into a larger number of arguments presented and solutions proposed, and groups that consider more arguments and solutions tend to reach outcomes that are more complex and

166. It should go without saying that a full account of the dynamics of diversity is beyond the scope of this article. For a recent book-length treatment of that issue, see SCOTT E. PAGE, The Difference: How tHE POWER OF Diversity CREATEs BetTer Groups, FTRMS, Schools, AND SOCIETIES (2007).

167. See, e.g., Deborah Gruenfeld et al., Group Composition and Decision Making; How Member Familiarity and Information Distribution Affect Process and Performance, 67 ORganizational BeHAV. AND HuM. DeCision Processes 1, 4 (1996) (informational diversity increases chances of group arriving at correct answer); Charlan Jeanne Nemeth, Differential Contributions of Majority and Minority Influence, 93 PsycHOL. REV. 23, 25 (1986) (informational diversity leads to more complex solutions)

168. See Susan E. Jackson, Team Composition in Organizational Settings: Issues in Managing an Increasingly Diverse Work Force, in GROUP PROCESS AND PRODUCTIVITY 138, 146 (Stephen Worchel, Wendy. Wood \& Jeffry A. Simpson eds., 1992) (claiming that for problem-solving tasks with correct answers, "mixed-attribute groups should outperform homogeneous groups when attribute heterogeneity increases the probability of the group containing some members who are capable of determining the correct answer to the problems being solved"); see also Adrian Vermeule, Common Law Constitutionalism and the Limits of Reason, 107 CoLUM. L. REv. 1482, 1490-91. (2007) [hereinafter Limits of Reason] (discussing the benefits of informational diversity for problems governed by Condorcet's Jury Theorem)

169. See infra Part III.C.4 (describing how the majority of Supreme Court cases lack a clearly identifiable answer).

170. See Gruenfeld, supra note 167 , at 4 (" $[\mathrm{H}]$ eterogeneous groups outperform homogeneous groups on tasks requiring creative problem solving and innovation, because the expression of alternative perspectives can lead to novel insights."); Nemeth, supra note 167, at 25 ("Those exposed to minority views are stimulated to attend to more aspects of the situation they think in more divergent ways, and they are more likely to detect novel solutions or come to new decisions.").

innovative. ${ }^{171}$ Moreover, diversity logically increases the likelihood that at least one member of the group will voice disagreement or skepticism with the proposed outcome. The presence of a devil's advocate forces a group to test assumptions and can generally reduce the incidence of deliberative failures like groupthink and informational cascades ${ }^{172}$ In short, increased diversity can simultaneously promote good deliberation and combat bad deliberation.

So far, all of this appears to point in the direction of a larger Court Increasing size is likely to produce greater diversity, and more diverse groups enjoy significant advantages in the solution of complex problems. ${ }^{173}$ But increased size is not an absolute good. For one thing, although size and diversity tend to run together, a larger court does not guarantee the presence of more informational perspectives. A court may be both large and homogenous. That aside, there are more serious reasons for worry.

First, the functional benefits of diversity require diversity of a certain kind. ${ }^{174}$ Informational diversity, and not demographic or value diversity, is

171. Harry $\mathrm{T}$. Edwards, The Effects of Cotlegiality on Judicial Decision Making, $151 \mathrm{U}$. PA. L. REV. 1639, 1667 (2003) (diversity leads to "better decisions because of an increase in the skills, abilities, information, and knowledge that diversity brings"); Gruenfeld, supra note 167 at 4 ("' $[\mathrm{H}]$ eterogeneous groups outperform homogeneous groups on tasks requiring creative problem solving and innovation, because the expression of alternative perspectives can lead to novel insights."); $i d$. (inclusion of a vocal deviant "can lead groups to generate more arguments, apply more strategies, detect more novel solutions, use multiple perspectives simultancously, and generally outperform groups without this type of influence") (citations omitted); Karen A Jehn et al., Why Differences Make a Difference: A Field Study of Diversity Conflict and Performance in Workgrous, 44 ADMN SCI Q. 741, 747 (1999) ("When a task is complex... discussing and debaring constring and debating competing perspectives and approaches is essetilal .... Th constructive discussions and debates needed to accomplish complex tasks depend on the availability of informational diversity."); Nemeth, supra note 167, at 26 (when divergent minority viewpoints are added, "the quality of the decision (whichever is selected) tends to be better because more alternatives are considered ... [and] novel correct solutions are capable of being detected"); see Charlan Jeanne Nemeth \& Julianne L Kwan, Minority Influence Divergent Thinking and Detection of Correct Solutions, 17 J. APPLIED SOC. PSYCHOL. 788 (1987) (presence of minority viewpoints can lead to the use of more varied strategies).

172. See IRVING L. JANIS, GROUPTHINK 267-68 (1982) (explaining how the presence of a devil's advocate can help prevent groupthink); Sunstein, supra note 144, at 1015-16 (suggesting that the presence of a devil's advocate may provide a temedy to informational ascades).

173. See Lempert, supra note 148 , at 685 ("Most apparent reasons for the superiority of large groups over small groups, and of all groups over individuals, derive from the participation of a greater number of individuals with more diverse viewpoints in the problem-solving (effort:)

174. Jehn et al., supra note 171 , at 759 ("[D]iversity itself is not enough to ensure movation; the nature of the team's diversity is critical."). 
[Ariz. St. L.J.

at the root of the functional claim. ${ }^{175}$ This limitation is important in part because it raises a potential conflict with the inclusion and legitimacy claims for diversity, which emphasize diversity in demographic rather than informational terms. The pursuit of demographic diversity might simultaneously produce increased informational diversity, but the overlap between the two is certainly not complete. ${ }^{176}$ For that reason, a commitment to the functional claim may look quite different in practice from a commitment to either of the competing claims. This qualification is also important because certain forms of non-informational diversity may actually hinder effective group performance. In certain contexts, for example, demographic diversity can restrict group deliberation by raising communication barriers and triggering stereotyping. ${ }^{177}$ These barriers should increase as group size expands because larger groups have a greater tendency to break down into smaller self-segregated groups. ${ }^{178}$. Thus, even if increased size produces gains in both demographic and informational diversity, group performance may nonetheless suffer if the barriers created make it more difficult for the group to communicate and integrate informational inputs. More damaging still is the prospect of value diversity, which "occurs when members of a workgroup differ in terms of what they think the group's real task, goal, target, or mission should be." ${ }^{179}$ Value diversity makes it more difficult for a group to take advantage of its informational diversity, ${ }^{180}$ and often leads to destructive emotional conflict. ${ }^{181}$ As with demographic diversity, it may be difficult to expand size

175. Williams \& O'Reilly, supra note 165 , at 87 ("functional or background diversity provides the range of knowledge, skills and contacts that enhances problem solving")

176. For an example, see supra notes 46 and 58 and accompanying text

177. Edwards, supra note 171, at 1669 ("Research on demographic diversity in organizations suggests that increased diversity of race, ethnicity, and gender can have negative effects on group functioning because it leads to increased gender can have negative communication more difficult and conflict more likely."). Williams \& at 104-14 (discussing how demonhic diversity functioning).

178. See Bray, Kerr \& Atkin, supra note 165, at 1233-34 (describing tendency for larger groups to break down); see also Jehn et a1., supra note 171, at 745 (describing social identity theory and self-segregation).

179. Jehn et al., supra note 171 , at 745.

180. See Allen C. Amason \& Harry J. Sapienza, The Effects of Top Management Team Size and Interaction Norms on Cognitive and Affective Conflict, 23 J. MGMT. 495, 496 (1997) (value 181. "can wreck a team's efforts to share information and reach consensus")

181. See Jehn et al., supra note 171 , at $759-60$ ("[G]roups that have greater diversity as measured in terms of values may suffer significant performance decrements... . and diminished worker morale. ..."); Williams \& O'Reilly, supra note 165 , at 121 (suggesting that group heterogeneity has the potential to result in better decisions but also increased that group conflict). and achieve informational diversification without risking simultaneous value diversification. ${ }^{182}$ In short, larger size may lead to greater diversity, but that increased diversity and size may not always be for the better.

Even if we are successful at promoting informational diversity and avoiding some of the pitfalls of demographic and value diversity, a second problem remains. Informational diversity produces benefits only when the group's competing perspectives are actually expressed and incorporated into the deliberative process. This means that norms of participation and attention are crucial to the diversity enterprise. ${ }^{183}$ But these norms often come under pressure in larger groups. ${ }^{184}$ One of the biggest obstacles to achieving the benefits of diversity is ineffectiveness in extracting and integrating competing perspectives from group members. ${ }^{185}$. The significance of that obstacle is sensitive to group size because average member participation tends to decline, ${ }^{186}$ and the number of nonparticipants tends to rise as groups get larger. ${ }^{187}$ This is because larger groups present fewer opportunities to speak, with the more aggressive members tending to seize those opportunities, ${ }^{188}$ and because large group size generates a sense that each member's opinion is relatively insignificant. ${ }^{189}$ Larger groups also

182. This is particularly true if the selection standards for the new members are different. On that basis, there is reason to be skeptical about Adrian Vermeule's suggestion of lay Justices on the Court. See Lay Justices, supra note 7.

183. See Jehn et al., supra note 171, at 747 ("When a task is complex ... discussing and debating competing perspectives and approaches is essential. . . ."); Jennifer R. Winquist \& James R. Larson, Jr., Information Pooling: When It Impacts Group Decision Making, $74 \mathrm{~J}$. PERSONALITY \& SOC. PSYCHOL. 371, 375 (1998) ("[O]nly the pooling of unshared information significantly influenced the quality of their decisions."). When group members effectively participate, they can inject unique information that will yield "better" results.

184. See John Fox \& Melvin Guyer, Group Size and Others' Strategy in an N-Person Game, 21 J. CONFLICT RESOL. 323, 325-26 (1977).

185. See Gruenfeld, supra note 167, at 1-2 (discussing how diverse groups "whose members know different facts are often ineffective at integrating their unique insights"); Jehn et al., supra note 171, at 744 (same); see also Gwen Wittenbaum \& Garold Stasser; Managemen of Information in Small Groups, in WHAT's SOCIAL ABOUT SOCIAL COGNITION? RESEARCH ON SOCIALly SHARED COGNITION IN SMALL GRoups 3-28 (Judith L. Nye \& Aaron M. Brower eds. 1996).

186. See, e.g., supra note 148.

187. See Bray, Kerr \& Atkin, supra note 165 , at $1233-34$ (" $[$ A $]$ s group size increases, the number of 'marginal' group members increases .....").

188. See Bobby R. PATton \& Kim GifFIN, DECISION-MAKING Grour INTERACTION 73 (1978) ("In latger groups the members tend to stifle contributions as the more aggressive tend to dominate."); Philip E. Slater, Contrasting Correlates of Group Size, 21 SOCIOMETRY 129, 13234 (1958) ("Members of larger groups feel that the group is disorderly and wastes time and that its members are too pushy, aggressive, and competitive.")

189. See, e.g., A. Paul Hare, A Study of Interaction and Consensus in Different Sized Groups, 17 AM. SOC. REv. 261, 267 (1952) (concluding that members of large groups are "less 

suffer increased coordination problems and decreased cooperation, both of
which can decrease informational exchange.

Finding the ideal mix of diversity and size requires the maximization of some combination of informational perspectives and participation in the group process. On this basis, many studies have concluded that groups of four to six members can best incorporate the perspectives of all members. ${ }^{191}$ This does not mean, however, that pursuing the various forms of diversity through group expansion is hopeless. To the contrary, many of the obstacles that develop in larger groups may be counteracted through collegiality or leadership..$^{192}$ Collegial groups are better at promoting participation by all members, ${ }^{193}$ at avoiding stereotyping and communication breakdowns that

satisfied" because they "have fewer chances to speak" and feel that "their individual opinions are not important and therefore not worth presenting to the group").

190. See Moreland et al., supra note 163, at 13-14 ("[Large] groups often experience coordination problems that can interfere with their performance.... The performance of large groups can also be harmed by motivation losses associated with social loafing free iding efforts to avoid exploitation. There is more conflict among the mecial loafing, free tiding, and less likely to cooperate with one another.") (citations omitted).

191. See A. PAUL HARE ET AL., SMALl GROUP RESEARCH: A HANDBOOK 147 (1994) ("The optimum group size for many group discussion tasks is five members.") J Richard Hackm ("The Neil Vidmar, Effects of Size gud Task Type on Group Pe members."); J. Richard Hackman \& SOCIOMETRY 37, 48-49 (1970) (optis Type on Group Performance and Member Reactions, 33 five memie fiver Individual Versus Group Consensus Decision Making, 74 J APPLIED PsYci, Realistic Test of ("Unless groups are made up of low-ability members function of size until membership reaches five or six "), effectiveness appears to increase as a ("cross-functional teams should contain four to ("groups larger than size four were never felt to be toomers"); Slater, supra note 188, at 137 never felt to be too large")
. 192. In the context of the Supreme Court in particular and courts more generally,
collegiality has often been emphasized as a salve for group strain. See Edwards, supra at 1645 ("Collegiality is a process that helps to create the conditions for principled agreement, by allowing all points of view to be aired and considered."); see also COMM'N ON STRUCTURAL ALTERNATIVES FOR THE FED. COURTS OF APPEALS; FINAL REPORT 29, 35, 40,49, 60 (Dec. 18 , 1998) [hereinafter White Report] (explaining collegiality as an essential 49,60 (Dec. 18 , maintaining consistency and coherence on the U.S. Courts of Appeals and thus better relationships amongst the individual members of each circuit); Robert M. Parker \& Leslie J. Hagin, Federal Courts at the Crossroads: Adapt Or Lose!, 14 Miss (describing collegiality as "a critical element in Lur single individuals should be reviewed by others") conception that vital decisions made by scholarly attention, but anecdotal evidence is Comment, Treating Methodology, 108 Like Subdecisions Alike: The Scope of Stare Decisis as Applied to Judicial Ethics, 51 STAN L COLUM. L. REV. 681, 692 (2008); David Luban, Reason and Passion in Legal POS Inferior Courts Obey Superior CuRISRUDENCE 197-203 (1990); Evan H. Caminker, Why Must Inferior Courts Obey Superior Court Precedents?, 46 STAN. L. REV: 817, 845 (1994).
193. See Nore 193. See Norbert L. Kerr \& R. Scott Tindale, Group Performance and Decision Making, 55
ANN. REV. PsycHOL. 623, 626 (2004) ("Several recent meta-analyses indicate that more can accompany demographic diversification, ${ }^{194}$ and at converging on a common identity that can soften the effects of value diversity. ${ }^{195}$ Similarly, effective leaders can structure deliberation to encourage greater participation and can foster commitment to shared values about the group's goals. ${ }^{196}$ Despite this, increased group size still presents challenges, in part because both collegiality and leadership become more difficult to achieve as size increases, ${ }^{197}$ and also because too much of either can contribute to deliberative failures that undermine the benefits of diverse informational perspectives. ${ }^{198}$

In sum, diversity on the Court may be valued as an end in itself insofar as it promotes a sense of inclusion and legitimacy. Under that view, the quality of diversity likely to be sought will be based on identity or demographic characteristics, and the benefits attained are likely to increase steadily as size increases. Conversely, diversity may be valued instrumentally, as a way to enhance deliberation and produce superior outcomes. On this view, the quality of diversity likely to be valued will be based on perspective or informational characteristics, and the relationship between size and benefits may not be so linear. Increasing the number of Justices may be expected to increase the range of informational perspectives, but at a certain point, the number may become too large to solicit and process the competing perspectives effectively. Moreover, larger sizes may increase the potential for value diversity, which is associated with decreased group functionality. To counter these possibilities, we might

cohesive groups ... tend to be more productive . . . "); Brian Mullen \& Carolyn Copper, The Relation Between Group Cohesiveness and Performance: An Integration, 115 PSYCHOL. BULL. $210,224-25$ (1994) (explaining that performance tends to improve as cohesiveness increases).

194. See Jehn et al., supra note 171 , at 745 .

195. See Ángel Cabrera \& Elizabeth F. Cabrera, Knowledge-sharing Dilemmas, 23 ORG. SrUD. 687, 701 (2002) ("[O]nce groups were shown to have a common identity, individuals began to share more information."); Edwards, supra note 171, at 1664 ("Collegiality plays a very important role in 'institutionalizing' judges into [a] shared mission.").

196. Cf. Moreland et al., supra note 163, at 14 (noting the ability of certain moderators to decrease the disadvantages of increased group size).

197. See $e^{\dagger}$ Edwards, supra note 171 , at 1675 ("Smaller groups have the potential to interact more efficiently, making close and continual collaboration more likely."); Fox \& Guyer, supra note 184, at 324 (discussing how smaller groups tend to be more cooperative than large groups); A. Paul Hare, Group Size, 24 AM. BEHAV. SCIENTIST 695, 696 (1981) ("As each additional member joins a group, the number of potential relationships between individuals and subgroups increases rapidly, thus placing more demands on the leader in coordinating group activity.").

198. Ramon J. Aldag \& Sally Riggs Fuller, Beyond Fiasco: A Reappraisal of the Groupthink Phenomenon and a New Model of Group Decision Processes, 113 PSYCHOL. BULL. 533,542 (1993) ("Group cohesiveness is seen as a primary antecedent condition for groupthink and is known to result in dysfunctional forms of conformity behavior."). 
expect collegiality or directive leadership to become more highly valued as. size increases.

\section{C. : Participation, Efficiency, Cohesion, and Accuracy}

The discussion in Part I.C yielded four somewhat related claims: (1) the Court should decide cases efficiently and expediently; (2) the Court's decisions should be transparent and should reflect the participation of all members; (3) the Court should produce decisions that are coherent and capable of implementation by lower courts; and (4) the Court should produce decisions that are "correct" in some sense. As with impartiality and diversity, the number of Justices constituting the Court may have an impact on its ability to satisfy these claims.

\section{Efficiency and Expediency}

Plainly, the first claim-that the Court should decide cases efficiently and expediently-does not mean that the Court should reach decisions as quickly and as cheaply as possible. Flipping a coin would perform that trick quite nicely, but no one would suggest that as a desirable exemplar for judicial decision-making. Instead, what is meant here is that the Court should be structured so that unnecessary expenditures of time or resources are kept to a minimum. To some extent, this means that an assessment of efficiency and expediency is inextricably tied up with outputs; delays and expenses may be justified if they produce outputs that are measurably superior in one way or another. This in turn suggests that it is difficult to assess these characteristics in a vacuum.

But some analysis is possible. As an initial matter, the impact of group size on efficiency and expediency will depend on the characteristics of the tasks that are to be performed. If a task is purely divisible-if it can be performed by a single Justice-then the addition of new group members should permit the task to be performed in less time without affecting the per task cost. ${ }^{199}$ But the only purely divisible tasks on the Court are those which one Justice can perform in his role as circuit Justice, which is limited to considering applications for stays, bail, or extensions of time to file briefs. $^{200}$ Most tasks on the Court are not divisible, but redundant. ${ }^{201}$

199. Indeed, task division has famously been observed to enhance efficiency in other contexts; as with Henry Ford.

200. See SUP. CT. R. 22 (authorizing individual Justices to rule on such applications).
201. Preparing for argument and deciding cases are examples.
Because each Justice must perform non-divisible tasks, the addition of new Justices increases the costs of performing those tasks. It may also increase performance time since the task may be performed only as fast as the slowest Justice, and the likelihood of a slow Justice increases as the Court expands.

Some tasks are partially divisible so that expanding the size of the Court presents both advantages and disadvantages. Opinion writing is an example. One Justice has primary drafting responsibility, but the joining members may contribute to that opinion by offering changes in an exchange of written memos. ${ }^{202}$ Expanding the Court may expedite the decision of cases. More Justices means that more opinions may be worked on at once. But because more Justices must consider the opinion and more views must therefore be accommodated, the end result may actually be to increase delays.

Factors other than task definition may also contribute to the interplay between size on the one hand, and efficiency and expediency on the other. Increased collegiality should yield greater efficiency because norms of productivity and group commitment enhance group performance. ${ }^{203}$ Conversely, a loss of collegiality, particularly when coupled by increases in value diversity, may hamper efficiency because the group will devote resources to tasks such as mission definition and the cultivation of group identity. ${ }^{204}$ For both of these reasons, if collegiality is more difficult to achieve as group size increases, then a larger group size may contribute to drags on the cost and speed of task performance. Relatedly, participation may decrease as the group gets larger because members perceive that their contributions are not as significant. ${ }^{205}$ This effect is not necessarily connected to a loss of collegiality but can contribute to diminished efficiency just the same. ${ }^{206}$ Thus, on the whole, the expectation with respect

202. See Leflar, supra note 15, at 723 ("Although the writing of a court's opinion is customarily and almost necessarily assigned to a single judge, it is expected that all the judges

take an active part both in reaching the conclusion that decides the case and in agreeing, or disagreeing, with the opinion that sets out the facts and reasoning which by serving the court's (not just the individual judge's) common-law-making function, constitute a guide to future decisions in comparable cases.").

203. See, e.g., Kerr \& Tindale, supra note 192 , at 626

204. See Hare, supra note 197, at 699 ("IA]n increase in group size . . . tends to . . reduce members [sic] feelings of identity with the group and commitment to its values . . ..") (emphasis omitted).

205. Hare, supra note 189 , at 267 .

206. The size of the Supreme Court may affect efficiency and expediency in other parts of the federal court system. If a larger Supreme Court size produces opinions that are more fractured, the result may be to introduce inefficiency and delay into the lower levels of the system because more resources will have to be devoted by lower courts to sorting out how the 
to the expansion of the Court might be increased efficiency up to the point where collegiality becomes difficult to sustain, and decreasing marginal
returns thereafter. ${ }^{207}$

\section{Participation}

The points just made are also relevant to claims relating to participation. Indeed, the earlier discussion on diversity makes most. of the essential points about participation and deliberation, so a summary should suffice here. ${ }^{208}$ On a weak version of the participation claim, each Justice would simply need to be afforded the opportunity to participate in the decision, but the quality of that participation could be minimal. Variations in size are not likely to affect the Court's ability to satisfy this claim; some method of polling votes should be possible regardless of size. But a stronger version of the participation claim seeks to ensure participation of a certain character and quality, and it is here that size may make a difference. To begin, there is an interaction between this form of participation and efficiency; achieving a constant level of participation with a larger size should require additional resources. For example, the time allotted for oral argument might be expected to rise if the number of Justices increases, which will impose additional resource costs since oral argument is a redundant task.

More important, size may have a direct effect on the Court's ability to satisfy the demands of the strong participation claim. Smaller groups tend to produce greater levels of participation. ${ }^{209}$ As groups get larger, participation may diminish for a number of reasons, including: a breakdown of group identity, free-loading, a perception that participation is futile, or a reduced

Supreme Court's decisions should be interpreted and implemented. Cf. Diarmuid F O'Scannlain, Should the Ninth Circuit Be Saved?, 15 J.L. \& POL. 415, 418 (1999) (discussing
the effects of circuit size on coherence).

207. See Hare, supra note 197, at 696-97 (after a certain point, "the addition of new members brings diminishing returns").
208. See supra notes $191-97$ and accompanying text.

209. See Nicolas Fay, Simon Garrod \& Jean Carletta, Group Discussion as Interactive Dialogue or as Serial Monologue: The Influence of Group Size, 11 Piscussion as Interactive (2000); see also Hare, supra note 197, at 705. The conv Size, 11 PSYCHOL. SCI. 481, 48 produce less participation from individual at 705 . The converse holds as well: larger groups Brian Mullen et al., Group Cohesiveness members. See Fay, Garrod \& Carletta, supra at 481 Tests of the Groupthink Hypothesis, 25 SMAL Quality of Decision Making: An Integration of tend to encourre dein Hypothesis, 25 SMALL GROUP RES: 189, 194 (1994) ("Larger groups tend to encourage deindividuation among group members and thereby render less participation
and poorer performance among group members.").

sense of responsibility. ${ }^{210}$ Enhancing collegiality or direct leadership can combat these tendencies, but these solutions are themselves more difficult to implement as size expands. ${ }^{211}$ Thus, although there may be other reasons to add members, ${ }^{212}$ smaller is more robust from the standpoint of the participation claim.

\section{Coherence}

The Supreme Court does not operate in isolation. To the contrary, the Court is part of a complex system, and it cannot and does not make every decision in that system. Rather, its decisions must be interpreted and applied by a large number of other actors, ranging from federal appellate courts to administrative agencies to police officers to the President of the United States. This leads to a third desirable Court characteristic: opinions that can be easily interpreted and applied. ${ }^{213}$ For simplicity, we will refer to this quality as coherence.

Size and collegiality may both affect the coherence of group decisions. A larger group, particularly one that has a more diverse range of informational or value perspectives, is less likely to reach decisions that are agreed upon by the entire group, and the lack of consensus may have a negative impact on coherence. For example, imagine that the addition of new members introduces greater value diversity into the group. If this occurs, it will be

210. Senator Maclay made a similar observation during the debates on the Judiciary Act of 1789 in arguing that a Court of six members would be too large, stating that "numbers rather lessened responsibility." MACLAY'S DIARY, supra note 156, at 413-14. Likewise, Senator Trumbull argued in 1869 that expanding the Court beyond nine might reduce "the sense of personal responsibility" for each Justice. CONG: GLOBE, 40th Cong., 3d Sess. 1484 (1869).

211. See Hare, supra note 189 , at 267 (explaining that as group size increases, "the trend toward factionalism ... should become more apparent"); Hare, supra note 197, at 696 ("As each additional member joins a group, the number of potential relationships between individuals and subgroups increases rapidly, thus placing more demands on the leader in coordinating group activity.").

212. One reason already discussed is to insert a wider range of viewpoints into the deliberation. Viewed a certain way, enhancing diversity may increase the quality of participation if group members are forced to respond to competing perspectives.

213. See Ruth Bader Ginsburg, Remarks on Writing Separately, 65 WASH. L. REV. 133, 150 (1990) ("[J]urists in the United States might serve the public better if they beightened their appreciation of the values so prized in the civil law tradition: clarity and certainty in judicial pronouncements."). This burden means that an ideal Supreme Court opinion may be one that produces a sub-optimal set of outputs, but that does so at a lower cost and/or with a lower risk of error than an opinion that attempts to produce the optimal set of outputs. Decisions that coherence may lead to additional conflict in other parts of the system-in lowe federal couck for example-and can in that sense create more problems than ate solved See O'Scarts supra note 206 , at 418 . 
more difficult to define the group's goals and to reach an agreed set of decisional norms. ${ }^{214}$ This might introduce inefficiency as the group expends time and resources to reach a value consensus, ${ }^{215}$ or it might simply lead the group to proceed with an "incoherent collective view or program" as a way to "avoid interminable wrangling." 216 In terms of outputs, this form of incoherence would increase the number of incompletely theorized agreements. ${ }^{217}$ This is not necessarily a bad thing, ${ }^{218}$ but it makes interpretation and application of Court decisions more difficult.

Similarly, an increase in informational diversity may generate incoherence. A lack of unanimity with respect to the decisional result increases the likelihood of fractured decisions involving some combination of concurring and dissenting opinions. The presence of multiple opinions in a given case may have rule of law effects if the fractured nature of the decision generates confusion about its precise contours. ${ }^{219}$ Even when disagreements do not produce separate opinions, they may lead Justices to compromise by developing imprecise legal standards or by refusing to resolve the legal issue at all. The result will often introduce inefficiency and delay into the lower levels of the system because more resources will have to be devoted by lower courts to sorting out how the Supreme Court's decisions should be interpreted and implemented. ${ }^{220}$ One, therefore, may value unanimity of opinion as a source of coherence and that may militate in favor of smaller group size. ${ }^{221}$

214. See Hare, supra note 197, at 699 (claiming that as the size of a group increases, the group itself requires "a clearer definition of the norms and a greater degree of role differentiation if the group is to make the best use of its resources while group solidarity is more difficult to maintain") (emphasis omitted)

215. See Hare, supra note 197, at 696-97 (adding new members creates a situation where "[t]he time for task completion is reduced at the expense of lowered efficiency per unit of time and the range of ideas available is increased at the expense of eficiency per unit of time, consensus in the absence of any clear-cut criteria for judgment"): 163, at 13-14 (larger cre of "y clear-cut criteria for judgment"); Moreland et al., supra note

216. Adrian Vermeule, Many-Minds Arguments in Legal Theory, 1 J. LEGAL ANALYSIS 1,
21 (2009) [hereinafter Many-Minds] (2009) [hereinafter Many-Minds].

217. See Cass R. Sunstein, Incompletely Theorized Agreements, 108 HARV. L. REV. 1733,
1735-36 (1995). 35-36 (1995)

218. Many-Minds, supra note 216, at 21 (explaining that proceeding without group consensus "may well have pragmatic virtues, enabling the group to move on and get something
done").

219. See, e.g., Edwards, supra note 171, at 1651 ("A multiplicity of opinions in a single case can contribute to confusion about what the law is."); Ginsburg, supra note 213 , at 148 ("More unsettling than the high incidence of dissent is the proliferation of separate opinions with no single opinion commanding a clear majority.").

220. See supra note 206.

221. See George E. Manners, Jr., Another Look at Group Size, Group Problem Solving, and Member Consensus, 18 ACAD. MGMT. J. 715, 723 (1975) ("If the degree of consensus is of
As with many other characteristics already discussed, the general relationship between size and collegiality may create second order coherence effects. At first blush, the direction of those effects is unexpected. One might think that collegiality contributes to incoherence because it may lead a majority to introduce ambiguity into legal rules to accommodate colleagues who are uncomfortable with the test that the majority otherwise would propound. ${ }^{222}$ In practice, however, collegiality may increase coherence because collegial groups, consisting of members who are comfortable expressing disagreement, may be more willing to dissent. ${ }^{223}$ Although fractured decisions pose the risk of incoherence, the positive relationship between collegiality and coherence stems from the fact that the quality of dissent is enhanced when the decision-making group is collegial. ${ }^{224}$ Thus, although dissents may still occur on collegial courts-and indeed

primary importance, it is useful to choose a smaller group, e.g., three to five so that each member can have his concern considered and discussed." (quoting Cummings, Huber \& Arendt supra note 148, at 473)). Of course, unanimity in smaller groups may sometimes be due to the absence of valuable informational perspectives that can contribute to higher quality decisionmaking, which suggests a tradeoff between unanimity and quality. See Manners, supra note 221 , at 723 . Moreover, unanimity may reflect a decrease in the depth and specificity of the opinion. See Donald R. Songer, Consensual and Nonconsensual Decisions in Unanimous Opinions of the United States Courts of Appeals, 26 AMER. J. PoL. SCI. 225, 226-27 (1982). If a unanimous opinion reflects a shallow and incompletely thcorized agreement, then unanimity may actually run counter to the interest in coherence. Still, the general point remains: a smaller group should be more likely to reach an agreement that is unanimous and complete, which means that small size and coherence may run together.

222. A justice who disagrees with a proposed result may write a dissent or may bargain to extract modifications in the reasoning of the majority opinion. See Stephen J. Choi \& G. Mitu Gulati, Trading Votes for Reasoning: Covering in Judicial Opinions, 81 S. CAL. L. REV. 735 740-(2008) (suggesting that judges on a mixed panel may choose to trade votes for reasoning); Frank B. Cross \& Emerson H. Tiller, Judicial Partisanship and Obedience to Legal Doctrine: Whistleblowing on the Federal Courts of Appeals, 107 YALE L.J. 2155, 2159, 2172 (1998) (suggesting that judges on a mixed panel may moderate their votes to avoid dissent). And collegiality may promote more of the latter than the former. See Edwards, supra note 171, at 1650. But see Ginsburg, supra note 213 ; at 148 (disagreeing with the latter conclusion).

223. See Robert S. Dooley \& Gerald E. Fryxell, Attaining Decision Quality and Commitment From Dissent: The Moderating Effects of Loyalty and Competence In Strategic Decision-Making Teams, 42 ACAD. MGMT. J. 389, 398 (1999) ("LL]oyalty facilitates the constructive processing of dissenting opinions during the course of the strategic decisionmaking process."); Edwards, supra note 171, at 1646-47 ("Social science studies on group composition and decision making offer some support for the idea that collegiality may make disagreement more comfortable and more likely, not less."); Gruenfeld, supra note 167, at 2 ("Interpersonal knowledge possessed by familiar group members should also reduce conformity, and the suppression of alternative perspectives and judgments.").

224. As Judge Edwards has described it, "[o]n a collegial court, if there is to be a dissent in a case, judges will help one another to make dissenting opinions as effective as possible." Edwards, supra note 171, at 1651. See also Francis P. O'Connor, The Art of Collegiality: 
may even be more frequent - they are more likely to enhance coherence by clarifying the nature of the majority decision, rather than undermining it by introducing uncertainty about the validity of the result. Therefore, if a sufficiently large group size renders collegiality difficult to achieve, the result may be not just more opinions, but opinions that are less coherent. ${ }^{225}$

\section{Accuracy}

Perhaps more than anything else, we would like the Supreme Court to reach "correct" decisions. ${ }^{226}$ Of course, merely stating that objective points out a serious difficulty, for it is a source of much debate whether there is such thing as a "correct" answer to a legal question. ${ }^{227}$.Without presuming to resolve that debate, we merely assume for present purposes that "legal questions admit of 'better' and 'worse' answers."228 When viewed this way, it should be clear that many of the other characteristics already identified and discussed are instrumental in the sense that they are ultimately directed at achieving "accurate" results. In particular, the values

Creating Consensus and Coping with Dissent, 83 MASs. L. REv. 93, 93 (1998) ("[D]issents are entirely consistent with collegiality.").

225. Coherence as a quality in group judicial decisions, and the relationship between that quality and the number of judges making those decisions, has been discussed at some length in the context of the federal appellate courts. See, e.g., White Report, supra note 192, at 35, 40 (arguing in favor of splitting the Ninth Circuit, because its large size "precludes close, regular, and frequent contact in joint decision making, and thus the collegiality that lets judges accommodate differences of opinion in order to produce a coherent body of law"): Parker \& Hagin, supra note 192, at 253-54 ("The law of the circuit with its atody of law.); Parker \& best be created and preserved by a body of judges small enough to function predictability, can believe the functional limit to such a court is twelve."); John C. Eastman, How Large Is Too Large for the Rule of Law? Testimony Before the U.S. Senate Judiciary Committee, Hearing to Consider Proposals to Split the Ninth Circuit Court of Appeals, Chapman Univ, Sch. of Law Consider Proposals to Split the Ninth Circuit Court of Appeals, Chapman Univ. Sch. of Law
Legal Studies Research Paper No. 2007-01, 2 (2006) available at http://ssrn.com/abstract $\approx 934234$ ("Now with 28 active judgeships, there are simply too many cases and too many judges in the Ninth Circuit to effectively administer justice in an efficient and conesive manner") The concerns raised there about th sizes with respect to cohere may have some application state the obvious there are significant dife state the obvious, there are significant differences between decision-making in the federal appellate courts and in the United States Supreme Court. Most notably with respect to coherence, appellate courts decide in rotating panels consisting of a sub-group of the entire court, whereas the Supreme Court has traditionally decided all cases en banc. See O'Scannlain, supra note 206, at 419 . Thus, some arguments based on the difficulties in maintaining coherence when the permutations of panels becomes unwieldy do not cleanly apply.

226. There is a possibility that under certain conditions we might prefer a decision that is incorrect. See, e.g., Cass R. Sunstein, If People Would Be Outraged By Their Rulings, Should incorrect. See, e.g., Cass R. Sunstein, If People Wo
Judges Care?, 60 STAN. L. REV. 155, 186-91 (2007)

227. See, e.g., DWORKIN, supra note 82, at 118-23; POSNER, supra note 192.

228. Caminker, supra note 192; accord Connors, supra note 192; Luban, supra note 192 associated with promoting high-quality deliberation-collegiality, informational diversity, impartiality, participation, etc.-are favored largely because they promise to deliver a constructive exchange of opinions and perspectives that will generate superior, or more accurate, decisions. ${ }^{229}$

But there may be a more straightforward relationship between size and accuracy. Accuracy might be promoted not through the productive interaction of views, but through their simple aggregation. ${ }^{230}$ Under an aggregation model, high-quality deliberation -or, indeed, deliberation of any kind-is unnecessary. ${ }^{231}$ Instead, accuracy derives from pooling together the individually held views of group members. ${ }^{232}$ Perhaps the most well-known aggregation claim is the Condorcet Jury Theorem ("Theorem"), which states that groups operating under a majority voting rule can select the correct result from two competing options so long as the average group member is at least slightly more likely to be right than wrong. ${ }^{233}$ If the Theorem holds, then a larger group will outperform a smaller one, ${ }^{234}$ indeed, a larger group will often outperform a smaller group with a higher average of competence. ${ }^{235}$ Clearly, this suggests that a larger Court may be desired, at least until the probability under the Theorem of achieving a correct answer approaches one.

The question, then, is whether the Theorem applies in the context of the Court. Much has been said on this subject, and we will not attempt to do

229. See supra notes $175-77$ and accompanying text.

230. Kornhauser \& Sager, supra note 1, at 99-102.

231. Indeed, some have suggested that deliberation has the potential to destroy the power of informational aggregation. See, e.g., Many-Minds, supra note 216, at 6 (suggesting that Rousseau feared that deliberation would compromise aggregation). In practice, deliberation will undermine the application of the Condorcet Jury Theorem only if the votes cease to become independent in the sense that one Justice's vote is determined (not simply influenced) by the vote of another. See Limits of Reason, supra note 168, at 1496.

232. See Many-Minds, supra note 216 , at 6.

233. Limits of Reason, supra note 168 , at 1490 ("In its simplest form, the Jury Theorem states that, where there is a binary choice and a right answer exists, and where average competence exceeds .5-that is, the average member of the group is more likely than not to choose correctly-then the likelihood that a majority vote of the group will produce the right answer approaches certainty as the group becomes larger or as average competence increases") The Theorem has been extended to cover more than two choices. See Christion List \& Robert Goodin, Epistemic Democracy: Generalizing the Condorcet Jury Theorem 9 J. Por PHL 277 283-88 (2001) available at (2001), available at hitp://www3.interscience.wiley.com/cgi-

234. Kornhauser \& Sager, supro 234. Kornhauser \& Sager, stipra note 1, at 98 ("The fact that there are more judges on a
panel thus implies that the panel is more accurate, i.e., more likely to reach the correct decision.").

235. Many-Minds, supra note 216 , at 5 ("[A] large enough number of fairly poor (but better than random) guessers can easily prove more competent than a small panel of highiy competent experts."). 
anything more than summarize the prevalent arguments here: Essentially, there are two primary barriers to the Theorem's application to Supreme Court decision-making. First, in its classic form, the Theorem applies to situations where there is an exogenously defined correct answer. ${ }^{236}$ Even if we assume that right answers are possible in law, exogenously defined correct answers are present only in some subset of cases, namely those where one of the following conditions is met: "(1) there is a factual component to the legal question; (2) there is a prescriptive or means-end judgment about which legal ruling will best conduce to achieving an agreed-upon goal; (3) the legal question, although neither factual nor prescriptive, otherwise has a right answer somehow defined" through philosophy, morality, or contemporary culture. ${ }^{237}$ No doubt, a substantial number of cases do no not fall within these categories; they do not have exogenously "right" answers. For them, the Theorem does not hold. Second, even for those cases where the condition of an exogenously defined correct answer is satisfied, there is a potential barrier associated with the requirement of independence. ${ }^{238}$ The cause for concern is not deliberation, ${ }^{239}$ but correlated bias. "Random distribution of bias is a major force behind the Jury Theorem," ${ }^{240}$ but if the Court is made up entirely of lawyers with similar backgrounds, ${ }^{241}$ then they are "likely to err in systematic rather than random ways," 242 and the systematic nature of the

236. Limits of Reason, supra note 168, at 1491 ("The Jury Theorem (in its informational interpretation) requires only an exogenous right answer....").

237. Limits of Reason, supra note 168, at 1491. An example of the last category of cases is one where the "correct" answer is simply the one that captures the "preferences of some defined
group, such as the population at large." Id. at 1490 .

238. See Many-Minds, supra note 216 , at 3,6 .

239. Limits of Reason, supra note ' 168 , at 1496 ("Independence is not violated by mere deliberation, or just because people influence one anothers' views.")

240. Limits of Reason, supra note 168, at 1500; see also Many-Minds, supra note 216, at 6 ("The issue of correlation is just as important as the issue of accuracy ...."). The probability of
reaching the correct answer by majority rule is inversely related to the correlation of bias among group members. Krishna $\mathrm{K}$. Ladha, The Condorcet Jury Theorem, Free Speech, and Correlated Votes, 36 AM. J. POL. SCI. 617, 625-30 (1992).

241. Justices over time have almost exclusively been selected from the population of lawyers, and "[m]ost lawyers, whatever their background, have a narrow, professionally inflected perspective on governance.". POSNER, supra note 55, at 128. More recently, the selection pool has tended to be even narrower, and has included only those lawyers with previous experience as an appellate judge. Epstein, Knight \& Martin, supra note 57 , at 938 ("Over thirty years have elapsed since anyone lacking judicial experience has ate 57, at 938 Court, and it has been over twenty since anyone has reached the couperience has ascended to the served as a federal appellate judge.").

242. Limits of Reason, supra note 168, at 1501. For a discussion of relevant biases, see Nobert L. Kerr, Robert J. MacCoun \& Geoffrey P. Kramer, Bias in Judgment: Comparing Individuals and Groups, 103 PSYCHOL. REV. 687, 687-89 (1996). errors will undercut group performance. ${ }^{243}$ This concern connects diversity and accuracy, and suggests the possibility of background diversity as a desirable compositional goal for the Court. ${ }^{244}$ All of this connects to size and the Theorem in the following way. If background diversity is absent, then even a very large group may not satisfy the requirements of the Theorem, and it becomes more difficult to support a claim for increased size as a means of promoting accuracy. If background diversity is present, then the conditions for the Theorem may be met for some number of the Court's cases, and an expansion in size should increase the likelihood that the correct results are reached in those cases. ${ }^{245}$

\section{WORKING TOWARDS THE IDEALLY SIZED COURT}

\section{A. The Difficulty of Optimal Size}

The preceding sections have established that the size of the Court implicates a number of different potential benefits: impartiality, diversity, efficiency, participation, coherence, and accuracy. On the other hand, an overly large group imposes various costs. Increases without any effort to promote diversity may strengthen biases and undermine accuracy. Even when new members are thoughtfully chosen, enlarging the court still threatens to reduce accountability, impair collegiality, inhibit participation, in particular deliberations, and decrease efficiency.

243. Limits of Reason, supra note 168, at 1501 ("The correlation of biases across the decisionmaking group trades off against the competence of the group's members. Even if judges are elite experts, of very high average competence, their likemindedness reduces group performance overall ....").

244. Epstein, Knight \& Martin, supra note 57, at 953 ("[O]perating under the assumption that diverse groups perform their tasks more ably than homogeneous ones, a Court composed of Justices with different career backgrounds will make better choices than one replete with, say, U.S. court of appeals judges."); Lay Justices, supra note 7, at 1581-99 (suggesting that individuals skilled in nonlegal disciplines, including philosophy and economics, will add value to the Court and improve decision-making). Of course, background diversity might be highly correlated with value diversity, and so efficiency and coherence may suffer as a result supra text accor

245. Judge Posner suggests that, at the circuit level, increased court size may lead to fewer correct outcomes. See Richard A. Posner, Is The Ninth Circuit Too Large? A Statistical Study of Judicial Quality, 29 J. LEGAL STUD. 711, 717-18 (2000). The reasons he gives are inapplicable to the Supreme Court, except possibly his argument that incorrect outcomes may be attributable to a judge's decision to abandon decision-making norms, and smaller courts deter those defections because they increase the ability to detect them $1 d$ at 712 But defections likely to be detected on the Supreme Court, so long as the Court always sits en banc such that all the Justices are engaged in the decision-making process. 
Setting the size of the Court requires a balance of these costs and benefits. The Court is of optimal size when the marginal benefit of the addition of a Justice equals its marginal cost. But ascertaining that size is easier said than done. To start, it is difficult to determine what size would maximize any particular benefit in isolation. That difficulty is greatly exacerbated by the interaction of competing benefits. There is simply no assurance that each institutional benefit is maximized at the same size. A group of six members might for instance, maximize the benefits of deliberation, but a group of eleven might maximize accuracy. More important, setting a size to achieve one goal might undermine another. For example, expanding the Court to achieve greater diversity for inclusion purposes poses a risk to impartiality because the very notion of achieving greater inclusion reflects an effort to introduce a new bias on the Court. Conversely, reducing Court size to obtain effective participation, efficiency, and coherence may frustrate diversity.

How we set the size therefore depends on how we prioritize the goals of the Court. One who values broad representation of different demographic groups more than coherence or efficiency may prefer a Court of a different size than someone with opposite preferences. Thus, for example, Professor Onwuachi-Willig has recommended that the Court be increased to fifteen to increase diversity, ${ }^{246}$ while Chief Justice Hughes suggested that the Court be reduced to five to increase efficiency. 247 As these examples suggest, different people have different visions of the relative priority of the Court's functions, and there is unlikely to be agreement on what constitutes the "best" ordering for setting the size of the Court.

Another layer of complexity derives from the fact that institutional size is not the sole determinant of these characteristics. There are many other variables. One is the qualifications of each of the individual Justices. The diligence, intelligence, command of existing constitutional doctrine, and past experience of each Justice may affect the value that the Court itself places on efficiency, coherence, and accuracy. Another variable is collegiality; which increases comfort between the Justices, thereby facilitating open, productive deliberations and enhancing efficiency at any given size. ${ }^{248}$ These benefits were realized under Chief Justice Marshall when all the Justices lived amicably together in a boardinghouse. ${ }^{249}$ According to Justice Story, these conditions promoted "a mutual esteem.

246. Onwuachi-Willig, supra note 43 , at $1265,1273$.

247. BISKUPIC \& WITT, supra note 136 ("The Court could do its work, except for writing of the opinions, a good deal better if it were five rather than nine.").

248. See Edwards, supra note 171, at 1647-49; Parker \& Hagin, supra note 192, at 254.

249. JEAN EDWARD SMTTH, John MARSHALL: DEFTNER OF A NATION 286-87 (1996).

which makes even the labors of Jurisprudence light. . . . . We moot every question as we proceed, and familiar conferences at our lodging often come to a very quick and, I trust, a very accurate opinion, in a few hours." 250 Effective leadership is also important. An effective leader may build coalitions, help deliberation and efficiency by defusing conflict between Justices, ${ }^{251}$ and inculcate a commitment to shared values about the group's goals. ${ }^{252}$ For example, under Chief Justice Hughes, who is generally thought to have been a strong leader, ${ }^{253}$ the Court was productive and conferences ran smoothly. ${ }^{254}$ By contrast, under Chief Justice Stone's ineffectual leadership, conferences were acrimonious and interminable. ${ }^{255}$ In other

250. Id. By contrast, the strong animosity between Justice James Clark McReynolds, an anti-Semite, and Justice Brandeis greatly inhibited deliberation. See PHILIP J. COOPER, BATTLES ON THE BENCH: CONFLICT INSIDE THE SUPREME COURT 93 (1995). So strong was McReynolds' dislike of Brandeis that he would leave the conference whenever Justice Brandeis spoke. Id.

251. One example involves Chief Justice Melville Fuller, widely regarded as one of the better Chief Justices. Justice Oliver Wendell Holmes, Jr. had ridiculed Justice John Marshall Harlan II by stating of Harlan's opinion, "That won't wash." COOPER, supra note 250 , at 93. Chief Justice Fuller cooled Harlan's temper by motioning as though using a washboard and stating, "[s]till I keep scrubbing and scrubbing." Id; see also G. Edward White, The Internal Powers of the Chief Justice: The Nineteenth-Century Legacy, 154 U. PA. L. REV. 1463, 1498-99 (2006) (discussing Fuller's leadership skills).

252. See Moreland et al., supra note 163 , at $13-14$

253. Justice Frankfurter called him the "Toscanini Hughes,' the maestro, the man with the remarkable gift of bringing things out of people." COOPER, supra note 250 , at 171 ; see also Robert H. Jackson, The Judicial Career of Chief Justice Charles Evans Hughes, in THE SUPREME COURT AND ITS JUSTICES 98, 103 (Jesse H. Choper ed., 1987) ("Even when passions were running high and his own associates were in sharp division, he never lost his poise. He was an ideal presiding judge.").

254. See Laura Krugman Ray, The Road to Bush v. Gore: The History of the Supreme Court's Use of the Per Curiam Opinion, 79 NEB. L. REV. 517, 531-32 (2000) (describing how Hughes' leadership resulted in "a lean, efficient process that Hughes could describe to Congress, in the heat of the court packing battle, as keeping the Court abreast of its docket despite the advanced age of many of its members"); MERLO J. PUSEY, CHARLES EVANS HUGHES 671-77 (1951) (recounting how Hughes ensured smooth conferences and prevented cleavages).

255. See COOPER, supra note 250, at 94; William H. Rehnquist, Remarks of the Chief Justice: My Life in the Law Series, 52 DUKE L.J. 787, 803 (2003) "The conferences [under Stone] sometimes went on interminably. I think they were very likely the cause of much of the personal ill will which prevailed on the Court at this time."); see also MELVIN I. UROFSKY, Division AND DISCORD: THE SUPREME COURT UNDER STONE AND VINSON, 1941-1953, at 30-32 (1997). The Court experienced similar fates under other poor leaders. See Jeffrey B. Morris, Chief Justice Edward Douglass White and President Taft's Court, in SUPREME COuRT HistoRical SOCIETY PUBliCATIONS: 1982 YEARBOOK 40, 40 (William F. Swindler et al. eds., 1982), YEARBOOK 40, 40 (William F. Swindler et al. eds.,
available http://www.supremecourthistory.org/publications/images/SCHS_publications-1982.pdf ("Weaknesses as a manager, the infirmities of age, and too traditional a view of the role of a Chief Justice would greatly hamper his effectiveness."); see also PUSEY, supra note 254, at 28283 (recounting how, under Chief Justice White, the Court usually left over 150 cases on the docket undecided each term). 
words, collegiality and leadership may offset some of the problems that arise from a large group. But their ability to do so is limited. Collegiality and effective leadership become increasingly harder to obtain as group size increases. All of this goes to show that determining the optimal size of the Court cannot be done on a wholesale level. The ideal size depends on who is on the Court and what we want the Court to accomplish.

This is not to say that setting the Court size is hopelessly indeterminate. Some general conclusions are possible. For instance, given that one of the Court's functions is to provide guidance to lower courts, ${ }^{256}$ an evenly sized Court is undesirable because it presents more opportunity for an affirmance without opinion by an evenly divided Court. Moreover, because the presence of at least some other Justices advances all of the Court's institutional goals-except, perhaps, coherence-most would probably agree that the Court should consist of more than one Justice.

Beyond these general conclusions, one can draw more specific conclusions based on prevailing theories about the role of the Supreme Court in society. Normative arguments relating to the Court's role have functional implications because they prioritize the institutional goals of the Court, even if only implicitly. Although our goal here is not to examine all such theories, a few examples may illustrate the point.

One prominent theory emphasizes the importance of giving effect to public values through constitutional doctrine. ${ }^{257}$ Adherents to this theory should favor a relatively large Court. Accurately identifying public values requires a sufficiently large and diverse court to ensure recognition, and perhaps representation, of various public values. This benefit may come at the cost of reduced coherence, but those with a public-values orientation are likely to accept the tradeoff. For example, they may well conclude that it is more important that individual rights be maximally enforced than that those rights be enforced in a uniform way. Although the increased size may inhibit deliberation to some degree, other procedures, such as the ability to offer comments on another Justice's draft opinion and to write separate opinions, may compensate and provide an acceptable opportunity to express competing viewpoints.

Minimalists should also favor a larger Court. For minimalists, reaching the correct decision in the particular case under consideration is of

256. See Easterbrook, supra note 81, at 5 .

257. See, e.g., Owen M. Fiss, The Supreme Court 1978 Term-Foreword: The Forms of Justice, 93 HARV. L. REV. 1, 5-17 (1979); Henry P. Monaghan, Constitutional Adjudication:
The Who and When, 82 YALE L.J. 1363, 1363 n.3 (1973). paramount importance. ${ }^{258} \mathrm{~A}$ larger number of Justices may accomplish that goal, particularly under a theory of information aggregation. At the same time, minimalists do not strive for coherence; they think that the Court should avoid stating generally applicable rules, and should instead resolve cases on the narrowest possible grounds. ${ }^{259} \mathrm{~A}$ larger number of Justices may promote narrow decision-making because a broader majority may be harder to muster.

Other theories point towards a smaller Court. For example, some, like Justice Scalia, think that it is more important that the Court announce clear rules than that those rules be correct. ${ }^{260}$ Others, like Richard Fallon, do not necessarily agree that clarity trumps accuracy, but still remain committed to the idea that a Court should prioritize the development of clearly applicable standards. ${ }^{261}$ What unites these approaches is a fundamental emphasis on coherence. That emphasis may imply support for a smaller court-one of seven or perhaps even five members.

\section{B. Size and Procedure}

Setting the size of the Court large enough to realize the benefits of multiple membership will likely result in some of the costs associated with large groups. Studies have shown that a group that exceeds the relatively small size of four to six members potentially faces problems in deliberation, efficiency, expediency, and coherence. ${ }^{262}$ Groups may overcome these problems to some extent by adopting procedures that regulate the decisionmaking process and establish decisional norms. Some of the procedures that the Court has developed over time may be understood as efforts of that sort.

\section{Internal Procedures}

\section{a. Conference and Opinion Circulation.}

Enlarging a group poses several potential problems to deliberation. As a group gets larger, the percentage of those participating in deliberations

258. See Cass R. Sunstein, The Supreme Court 1995 Term-Foreword: Leaving Things Undecided, 110 HARV. L. REV. 4, 15 (1996) (stating that the focus of the minimalists is on "the case at hand").

259. SUNSTEN, supra note 10 , at $\mathrm{ix}-\mathrm{x}$, xiii.

260. Scalia, supra note 11 , at $1178-79$.

261. Fallon, supra note 75 , at 1313 .

262. See Moreland et al., supra note 163, at 12 ("[C]ross-functional teams should contain four to six members ...."). 
tends to decrease. ${ }^{263}$ This lack of participation not only undermines the information sharing benefits of deliberation, but also may lead to deliberative failures. ${ }^{264}$

Internal procedures may avoid these problems to some degree by promoting or compelling participation. Procedures may ensure a weak form of participation, under which each member has some minimal opportunity to participate in the decision, such as by providing his vote, or a stronger form of participation that requires each Justice to discuss each others' positions and engage in substantive deliberation.

For its part, the Court has adopted several procedures encouraging participation of various degrees. ${ }^{265}$. First, for each case argued the Justices hold a conference during which each Justice, beginning with Chief Justice and proceeding in seniority, indicates his vote and his reasons for it without interruption from other Justices. ${ }^{266}$ This format ensures that all Justices actually contribute their views and results in shared information for better decision making. ${ }^{267}$ Collegiality is also promoted during this conference through the rule that each Justice must shake hands with the others before they discuss cases. ${ }^{268}$

Although the conference forces participation, that participation is minimal. It does not involve any deliberation. ${ }^{269}$ The bulk of deliberation occurs after the conference through the exchange of draft opinions, comments on those drafts, and responding to separate concurrences and dissents. ${ }^{270}$ Unlike the conference, this procedure provides an opportunity

\section{See supra Part III.C.3}

264. See supra Part III.C.

265. When the Court consisted of only six members, the Court appears not to have found a need for formal procedures during deliberation. See White, supra note 251, at 1476 .

266. William H. RehNQUist, The Supreme CourT: How IT WAS, How IT Is 289-90 (1987).

267. Id. at $254-60$. 268. See SupremeCourtUS.gov, THE COURT AND ITS TRADITIONS (2001),
http://www.supremecourtus.gov/about/traditions.pdf ("When the Justices assemble to go on the Bench each day and at the beginning of the private Conferences at which they discuss decisions each Justice shakes hands with each of the other eight.").

269. Id: Stuart Taylor, Jr., Ruing Fixed Opinions, N.Y. TTMEs, Feb. 22, 1988, at A16, available at http://www.nytimes.com/1988/02/22/us/washington-talk-ruing-fixed-opinions.html (describing Justice Scalia's disappointment at the lack of deliberation at conference).

270. SUSAN LOW BLOCH, VICKI C. JACKSON \& THOMAS G. KRATTENMAKER, INSIDE THE SUPREME COURT: THE INSTITUTHON AND ITS PROCEDURES $562-63$ (2d ed. 2008). The Court has not always had procedures promoting deliberation. During the nineteenth and The Court has centuries, conferences had already taken on their. During the nineteenth and early twentieth Justices did not engage in issue that opinion without prior circulation See Whate assigned a majority opinion would that further deliberation was not posible bee White, supra note 251 , at 1471 . The sense was for each Justice to participate, not an obligation for each Justice to do so (except for the Justice assigned to draft the majority opinion). But this written procedure promotes participation by ensuring that Justices do not need to contend with each other to be heard. ${ }^{271}$ It also provides a better opportunity for the Justices to assimilate the information from the other Justices and to reflect on the points they raise than would a rapid oral exchange. ${ }^{272}$ Together, these procedures require minimal participation of each Justice and provide an opportunity for more substantive participation with minimal interference.

Oral argument provides another opportunity for deliberation among the Justices. But oral argument does not have any procedures ensuring even weak participation. No Justice is guaranteed the opportunity to speak; Justices vie with each other and the advocates to be heard. It therefore is unsurprising that oral argument tends to be dominated by several of the Justices, and that some Justices, like Justice Thomas, hardly speak at all. ${ }^{273}$

\section{b. Opinions for the Court.}

Since the early nineteenth century, the Court has issued single opinions for the court instead of seriatim opinions by each Justice. By all accounts, the Court adopted this practice not to overcome problems resulting from large size, but instead to increase the prestige of the Court's opinions. ${ }^{274}$ But on today's larger Court, the practice takes advantage of the benefits offered by a larger Court and helps to remove some of the costs of a large court.

271. This apparently is not the reason for the conference procedure. According to Rehnquist, the brevity of discussion at conference is due to the fact that oral presentations are inadequate to work out the details and nuances of reasoning. See WILLIAM H. REHNQUIST, THE SUPREME COURT 257 (Vintage Books rev. ed. 2002) (1987).

272. These deliberations all take place in private. Opening deliberations to the public increases transparency. Oral argument serves this function.

273. Mike Nizza, Clarence Thomas's Case for Shutting Up, THE LEDE: N.Y. TIMES NEWS BLOG (Nov. 30, 2007, 11:59 AM), http://thelede.blogs.nytimes.com/2007/11/30/clarencethomass-case-for-shutting-up/ (suggesting, a bit tongue-in-cheek, that his "colleagues should shut up!"); Clint Williams, Justice Thomas Extols the Need to Listen, FULTON COUNTY DAILY REP., Oct. 24, 2008, http://www.law.com/jsp/article.jsp?id=1202425512909 (recounting Justice Thomas's statement that judges should spend more time listening and less time talking). This is not to say that oral argument has no value. It certainly does provide Justices with information salient to resolving cases and generating new law. See, e.g., Timothy R. Johnson, James F Spriggs II \& Paul J. Wahlbeck, Oral Advocacy Before the United States Supreme Court: Does It Affect the Justices' Decisions?, 85 WASH. U. L. REV. 457, 525 (2007). It also promotes transparency by occurring in a public forum. The point being only that oral argument is not an ideal forum for deliberation because of the lack of procedures promoting participation.

274. Kevin M. Stack, The Practice of Dissent in the Supreme Court, 105 YALE L.J. 2235, 2239 (1996) ("Marshall's introduction of the 'opinion of the Court' gave the Court an institutional voice, a voice over and above that of its individual members."). 
To start, producing opinions for the Court promotes efficiency. Issuing opinions seriatim introduces redundancy into the decision making process as each Justice must spend time and effort producing an opinion. By contrast, issuing an opinion for the Court places the task of drafting an opinion on a single Justice, thereby freeing the other Justices to work on other tasks.

The practice of issuing a single opinion of the Court also fosters a norm of consensus. The Justices strive to produce opinions to which a majority of the Justices will subscribe. ${ }^{275}$ The need to find common ground may promote deliberation to achieve consensus. The norm of consensus also may reduce some of the friction that could otherwise result from broad value diversity among the Justices. Justices may compromise their preferences in order to secure a majority. ${ }^{276}$

One potential downside to compromise is that it may produce incoherence. Justices may deliberately leave an opinion ambiguous in order to secure a majority. ${ }^{277}$ Enlarging the Court may exacerbate the problem, since more views must be accommodated. But it is hardly clear that more cohesion would result if the Court were to abandon the opinion of the Court procedure and return to a seriatim procedure.

Incoherence results when no majority of Justices agrees on one set of principles for resolving a case. If each Justice were to write separately, they would produce conflicting opinions, leaving lower courts without any clear principle to apply in future cases. Different lower courts therefore might develop different doctrines, thereby necessitating further Supreme Court intervention. Moreover, even if the Justices did agree on certain principles, the costs of identifying them, and the chances of getting them wrong, would increase under a seriatim procedure, because lower courts would have to cull through the various opinions to find overlap among those opinions.

275. Neal Devins, Ydeological Cohesion and Precedent (Or Why the Court Only Cares About Precedent When Most Justices Agree with Each Other), 86 N.C. L. REv. 1399, 1414 (2008) ("Justices will often compromise their individual preferences regarding the reach of the decision."). This norm to produce a majority opinion is different from the norm of cons of during the nineteenth century, under which Justices sought to avoid all separate of consensus Epstein, Jeffrey A. Segal \& Harold J. Spaeth, The Norm of Consensus on the opinions. Lee Court, 45 AM. J. POL. SCI. 362, 362, 364-65 (2001) Norm of Consensus on the U.S. Supreme norm of consensus" followed by the Supreme Court) providing evidence of the "existence of a the Supreme Court).

276. Frank B. Cross, The Justices of Strategy, 48 DUKI L.J. 511, 521 (1998); Frank H. 277. See Rays of Criticizing the Court, 95 HARV. L. REV. 802, 815 (1982) 277. See RRENQUIST, supra note 266, at 302 (recounting statement of Chief Justice Charles
Evan Hughes that "if he needed the fifth vote of a colleague who insisted on putting in paragraph that did not 'belong,' in it went, and let the law reviews figure out what it meant");
Hart, supra note 7, at 111 .

That task inevitably becomes more difficult as the number of separate opinions increases.

\section{c. Timetables.}

An overly large Court poses problems for expediency in issuing decisions. Issuing decisions on a multi-member court is a time consuming process. A Justice who writes an opinion may need to modify the opinion to accommodate the views of other Justices; if a Justice cannot be accommodated, he will write a separate opinion, which may in turn generate additional opinions or responses from the majority opinion. Each of these steps takes considerable time, and as the number of Justices who must be taken into account increases, the amount of time increases. The Court has adopted an informal rule that it must dispose of all argued cases before recessing for the summer. ${ }^{278}$. This rule is designed to ensure that the court stays abreast of its workload, and it may encourage Justices to reach a compromise sooner rather than later.

\section{d. Certiorari pool.}

One procedure that takes advantage of the Court's size is the certiorari pool. The Supreme Court will exercise jurisdiction over a case only if four Justices vote to hear it. ${ }^{279}$ Traditionally, each Justice independently reviewed each petition to determine whether to grant review. ${ }^{280}$ But the enormous case load-the Court reviewed 8922 petitions for review in $2007^{281}$ - has rendered that virtually impossible. ${ }^{282}$ The certiorari pool alleviates the burden on the Justices by allocating most of the work associated with the determination whether to grant review in a case to a single law clerk, instead of having each of the Justices or their clerks perform that work separately. ${ }^{283}$ Under the procedure, one law clerk has the task of preparing a summary of each petition and a recommendation on whether the Justices should grant review. ${ }^{284}$ The pool thus seeks both to avoid unnecessary redundancy - each Justice and his clerks independently

278. EUGENe Gressmán ET AL., SuPREME COURT PRACTICE 11 (9th ed. 2007).

279. Richard L. Revesz \& Pamela S. Karlan, Nonmajority Rules and the Supreme Court 136 U. PA. L. REV. 1067,1069 (1988) ("Broadly speaking the Court will schedule full briefing and oral argument whenever four Justices agree that a case deserves plenary consideration.").

280. ARTEMUS WARD \& DAVID L. WEIDEN; SORCERERS' APPRENTICES: 100 YEARS OF LAW CLERKS AT THE UNITED STATES SUPREME COURT 109 (2006).

281. The Supreme Court, 2006 Term: The Statistics, 121 HARV. L. REV. 436, 444 (2007)

282. See Hart, supra note 7 , at $87-88$ (arguing that the Court could not give adequate consideration to each petition when over 1300 petitions per year were filed).

283. GRESSMAN, supra note 278 , at 40 .

284. Id. 
summarizing the facts and legal issues of a case-by dividing that work among the various clerks, and to preserve the important redundancy of each Justice independently voting whether to grant review.

Because the pool divides work among law clerks, the degree of its effectiveness depends on the number of law clerks, which in turn depends on the number of 'Justices participating in the pool. ${ }^{285}$ Currently seven Justices participate in the pool, and each provides four clerks. ${ }^{286}$ Adding another Justice and his clerks would permit more petitions to be summarized in the same amount of time, while subtracting a Justice and his clerks would have the opposite effect. ${ }^{287}$

\section{e. Acquiescence in Decrees.}

Achieving agreement among a majority may become more difficult as the size of the Court increases, because each new member adds at least partial new set of values. Diverse values not only may lead to separate opinions and under-theorized agreements, but also may hamper the Court's ability to reach a majority agreement on the proper disposition of a case, leaving the parties to the case without any sense of how to proceed. The Court has adopted an informal practice to avoid this problem. When a majority of the Court does not agree on a single disposition, some Justices may join a disposition with which they disagree but that roughly achicves the disposition they desire in order to ensure a majority disposition. Hamdi v. Rumsfeld, which considered whether the Government had legally detained Hamdi on the ground that he was an enemy combatant, provides an example. ${ }^{288}$ Four Justices voted to vacate the judgment of the court of appeals, which had held that the detention was proper, and to remand for further proceedings to determine whether Hamdi was an enemy combatant. ${ }^{289}$ Two others, Justices Stevens and Scalia, voted to reverse the court of appeals' judgment, concluding that the Government had no authority to hold Hamdi. ${ }^{290}$ Justice Thomas voted to affirm the judgment of the court of appeals. ${ }^{291}$ Finally, Justices Souter and Ginsburg agreed with

285. To be sure, the procedure of having only a single law clerk instead of many review certiorari petitions undermines the benefits of informational diversity instead of many review loss of diversity that Justices Stevens and Alito do not panal diversity. It is in part to offset this 286 Adam Liptak, $A$ Second Justice Opts Out participate in the pool.

N.Y. TIMES, Sept. 26, 2008, of a Longtime Custom: 'The Cert. Pool', http://www.nytimes.com $/ 2008 / 09 / 26 /$ washing 2008 , at A21, available at

287. Of course, the number of clerks could be increased.

288. Hamdi v. Rumsfeld, 542 U.S. 507,553 (2004)

290. Id. at 554 (Scalia, J., dissenting).

291. Id. at 579 (Thomas, J., dissenting) the plurality that the judgment should be vacated, but they disagreed with the plurality's decision to remand for an enemy combatant determination; instead, they would have remanded for proceedings consistent with their view that the Government had failed to justify holding Hamdi. ${ }^{292}$ Thus, no single disposition garnered the support of five votes. To enable the Court to render judgment, Justices Souter and Ginsburg concurred in the plurality's judgment, explaining that the plurality's remand was "on terms closest to those" they would have imposed. ${ }^{293}$

\section{Appointments}

The appointments process is intimately bound up with the size of the Court. Many of the benefits of a large court may be recognized only through a judicious use of the appointments process. For example, enlarging the Court can achieve informational or value diversity only if the President names a candidate who has information or values that differ from those of the Justices already on the bench. Aside from-merely failing to lead to benefits, injudicious use of appointments can make things worse. Appointing a homogenous bench may lead to deliberative failures like polarization. The appointments process also provides an opportunity to reduce some of the costs associated with a large court. The process may be used to screen candidates for their willingness and ability to work as part of a collegial body, as well as for the compatibility of each candidate's personality with those already on the Court. For the Chief Justice, it also provides an opportunity to screen for strong leadership skills.

Presidents have generally not sought to introduce value diversity onto the Court. Over the past few decades, the primary criteria for appointments appear to be that the appointee shares the same values and ideology as the appointing president and that the appointee be able to garner the votes of fifty senators. ${ }^{294}$ Although presidents have on occasion used the appointments process as a way to introduce gender; racial, and ethnic

292. Id. at 539 (Souter, J., concurring)

293. Id. at 553 (Souter, J., concurring) ("Since this disposition does not command a majority of the Court, however, the need to give practical effect to the conclusions of eight Members of the Court rejecting the Government's position calls for me to join with the plurality in ordering remand on terms closest to those I would impose.").

294. See David A. Strauss \& Cass R. Sunstein, The Senate, the Constitution, and the Confirmation Process, 101 YALE L.J. 1491, 1506 (1992) ("TT]here can be little doubt that recent Republican Presidents have made appointments on the basis of their criticisms of the Court

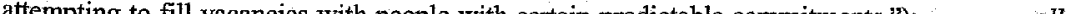
an WITres, Cons BEN WitTES, CONFIRMATION WARS: PRESERVING INDEPENDENT CoURTS IN ANGRY TIMES 1-14 (Peter Berkowitz \& Tod Lindberg eds., 2006). 
diversity, achieving that type of diversity has been of secondary importance the principal criterion has been that the potential appointee have the "correct" ideology. ${ }^{295}$

The consequence is that the current members of the Court range from moderates to strongly conservative; since the retirement of Thurgood Marshall, no Justice has held a liberal view of the Constitution. ${ }^{296}$ Those views continue to be important-indeed they underlie a good portion of extant constitutional law-and their absence from the Court deprives it of valuable perspective. ${ }^{297}$ Placing too much weight on ideology has several other consequences. Although presidents must have one preference, focusing too heavily on any single consideration risks compromising other qualifications that might improve the Court. And placing too much weight on ideology specifically might undermine collegiality by inculcating the sense in the appointee that he is one of "us" and not one of "them," especially if he faced opposition because of his ideology. Nor do presidents appear to have made concerted efforts to introduce informational diversity on the Court. Although each Justice has had some unique experiences, they all have similar educational backgrounds and previously served as circuit judges, and most worked in the executive branch. ${ }^{298}$ None has legislative experience. ${ }^{299}$ The relative homogeneity results in less available information for decision-making. ${ }^{300}$

By contrast, there is reason to think that the appointments process fares much better at screening candidates for their collegiality or other

295. Thus, "diversity" picks, such as Justices Ginsburg, Thomas, Scalia, O'Connor, and Marshall, all held ideologies that closely matched those of the appointing president.

296. Strauss \& Sunstein, supra note 294 , at $1510-12$.

297. Id. at 1512 ("These views cannot be characterized as marginal or as having nothing valuable to offer on their behalf. They have substantial support in the state and federa judiciaries, and from the public, Congress, professionals, and academics. Views of this sort provide a valuable perspective to the Court.").

298. See Epstein, Knight \& Martin, supra note 57, at 906-07. Every Justice except Justice Stevens graduated from an. Ivy League law school; Justice Stevens graduated from Northwestern. Six of the Justices served as lawyers in the executive branch of the federal government. See SupremeCourtUS.gov, The Justices of the Supreme Court, http://www.supremecourtus.gov/about/biographiescurrent.pdf (last visited Sept. 29, 2009) (biographies of Roberts, Scalia, Thomas, Breyer, Alito, and Sotomayor).

299. The last Justice with any legislative experience was Sandra Day O'Connor. See SupremeCourtUS.gov, The Justices of the Supreme Court, http:/www.supremecourtus.gov/about/biographiescurrent.pdf (last visited Sept. 21, 2009) (biography of Sandra Day O'Connor). The last Justice appointed who did not graduate from law

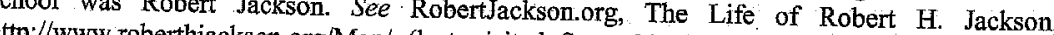
http://www.roberthjackson.org/Man/ (last visited Sept: 21, 2009) (biography of Robert H.

300. See Lay Justices, stupra note 7, at 1581-82. To be sure, the law clerks bring some additional level of information, but their backgrounds tend to be relatively similar as well. characteristics that would offset costs of a large court. Stories abound of nominees being picked based in part on their personality, which was assessed during personal interactions with presidents and their advisors. ${ }^{301}$ No doubt, senators likewise assess an appointee's personality, even if informally, during the routine courtesy calls that appointees pay to each senator. ${ }^{302}$ On a more formal level, senators regularly make statements regarding the importance of collegiality and management, ${ }^{303}$ ask questions about these topics, ${ }^{304}$ and give their assessment whether an appointee possesses those characteristics. ${ }^{305}$

\section{CONCLUSION}

How large should the Supreme Court be? There is no single answer. Setting the size of the Supreme Court is a difficult task that depends on how we perceive and define the role of that institution. Our goal is to contribute to a greater appreciation of the role that size plays in guiding the Court's performance and the lack of the role that performance has played in guiding the Court's size. Defining an ideal size properly requires the weighing of various indeterminate and often competing considerations. It demands the

301. JÁN CRAWFord GREenburg, SuPReme CONFLICT: THE INSIDE STORY OF THE STRUGGLE For CONTROL OF THE UNITED STATES SUPREME COURT 199, 248, 252 (2007).

302. William G. Ross, The Supreme Court Appointment Process, 57 ALB. L. REV. 993 1026 n. 138 (1994)

303. See Steve Goldstein, Specter Praises. Roberts for Chief, PHILA. INQUIRER, Sept. 7 , 2005 , at Al (Sen. Arlen Specter stating that he hoped Roberts would "work for consensus" and that "there needs to be a collegial, modest approach to try to bring the court together so that we have some idea of continuity.").

304. Confirmation Hearing on the Nomination of Samuel A. Alito, Jr. to be an Associate Justice of the Supreme Court of the United States: Hearing Before the S. Comm. on the Judiciary, 109th Cong. 491-92 (2006) (statement of Sen. Orrin Hatch), available at http://frwebgate.access.gpo.gov/cgibin/getdoc.cgi? dbname=109_senate_hearings\&docid=f:25429.pdf (asking Alito to explain the
role of dissents on a collegial court).

305. U.S. Senator Robert Bennett (R-Ut) Holds A Media Availability After Meeting With Judge Samuel Alito, Nov. 3, 2005, 2005 WLNR 17786114 (explaining importance of "civility and collegiality" on the Supreme Court, and expressing hope that Alito would "be a significant element in trying to make the Supreme Court work more smoothly than perhaps it has in the past"); Confirmation Hearing on the Nomination of John G. Roberts, Jr. to be Chief Justice of the United States: Hearing Before the S. Comm., 109th Cong. 15 (2005) (statement of Sen. Chuck Grassley), available at http://www.gpoaccess.gov/congress/senate/judiciary/sh109158/13-15.pdf ("The Chief Justice has to be someone who has a good management style, who can run the trains on time, and who can foster collegiality on the Court. So, Judge Roberts, I think that since you have appeared before the Court 39 times to argue cases on appeal, and that the current Justices know and respect you, that bodes very well in terms of your smoothly transitioning into the Court, into the new role now of Chief Justice:"). 
definition of the Court's institutional purpose and of a set of institutional features that will best serve that purpose. Size, in short, should be the result of a thoughtful and functional analysis rather than an artifact of political opportunism. For that reason, the historical record should be enough to suggest a reconsideration of Supreme Court size. ${ }^{306}$

We recognize that reassessing and perhaps changing the current size of the Supreme Court will likely meet substantial obstacles. The fact that the Court has remained at nine members for almost 150 years without serious mishap has almost certainly instilled a sense in the public that it should not be altered. ${ }^{307}$ Contributing to that perception is the possibility that, after Roosevelt's court-packing plan; even good-faith efforts to modify the Court are likely to be seen as driven by the partisan desire to achieve more politically favorable decisions. ${ }^{308}$ But this does not mean that a reassessment of size should not be made. Moreover, even in the absence of any modification, it is useful to take account of size. Whether chosen deliberately or by happenstance, the size of the Court has institutional consequences. Understanding these effects should improve our understanding of the Court's performance, its culture, and its procedures.

306. Indeed, even if the historical record suggested that the selection of nine as the ideal size was the reflection of just the sort of functional considerations we are advocating, we would still encourage reconsideration. The Court's role has substantially changed since that selection. In 1869 , the Court's primary task was to resolve disputes; since gaining discretionary jurisdiction in 1925, the Court's principal role has been to clarify the law and provide guidance to the lower courts. See Easterbrook, supra note 81 ; at 5. Administrability and coherence therefore have assumed a more important role, which may warrant adjustment.

307. See Adrian Vermeule, Politicat Constraints on Supreme Court Reform, 90 MINN. L. REv. 1154, 1162-63 (2006). Indeed; even in 1937, when the Court had a membership of nine for only sixty years, the perception was that the Constitution specified a Court of nine-as is exemplified by an elderly woman's statement that "[i] $f$ nine judges were enough for George Washington, they should be enough for President Roosevelt." Id. at 1163.

308. See generally id.

\section{RECONCEPTUALIZING JUDICIAL ACTIVISM AS JUDICIAL RESPONSIBILITY: A Tale of Two Justice Kennedys}

Eric J. Segall ${ }^{\dagger}$

\section{INTRODUCTION}

Most academics and politicians who accuse the Supreme Court of judicial activism focus on specific results to support their arguments. Conservatives rail against Court decisions protecting privacy and other noneconomic individual rights, ${ }^{1}$ whereas liberals criticize the Court's federalism, pro-business, and affirmative action decisions. ${ }^{2}$ Meanwhile, although a few law professors and political scientists have taken more nuanced multi-factor and empirical approaches to measure judicial activism, they also adopt as a central focus of their arguments attention to specific decisions by the Supreme Court. ${ }^{3}$ Because these attempts to use the term judicial activism as a measure of something important (and usually

$\uparrow \quad$ Professor of Law, Georgia State College of Law. I would like to thank Michael Dorf, Michael Gerhardt; Lori Ringhand; Mark Tushnet, and Patrick Wiseman for helpful comments on carlier drafts of this article, and Robert Ashe for invaluable research assistance. I feel obligated to note that several readers of this piece suggested that the title; which refers to "Two Justice Kennedys," is grammatically incorrect insofar as it should read "Two Justices Kennedy." The decision to not make that change was mine and mine alone.

1. See, e.g., Michael J. Gerhardt, The Rhetoric of Judicial Critique: From Judicial Restraint to the Virtual Bill of Rights, 10 WM. \& MARY BILL RTS. J. 585, 620-28 (2002) (canvassing the right wing's critique of the Warren and Burger Court decisions and suggesting that Ronald Reagan made the issue of judicial activism part of his political campaign against the left); Jeffrey Toobin, Swing Shift, THE NEW YORKER, Sept. 12, 2005 (quoting James Dobson, director of the group Focus on the Family, as saying that Justice Kennedy was "the most dangerous man in America" because of his decisions on gay rights and abortion).

2. See Adam Cohen, Last Term's Winner at the Supreme Court. Judicial Activism, N.Y. TIMES, July 9, 2007, at A16 (describing the conservative victories during the 2006-07 Term as "judicial activism" and motivated by a "conservative ideology").

3. See, e.g., William P. Marshall, Conservatives and the Seven Sins of Judicial Activism, 73 U. Coro. L. REv. 1217, 1219-55 (2002) (setting forth seven kinds of activist behavior); Lori A. Ringhand, Judicial Activism: An Empirical Examination of Voting Behavior on the Rehnquist Natural Court, 24 CONST. CommENT. 43, 43-67 (2007) (employing an empirical analysis of voting behavior to determine activist Justices); Ernest A. Young, Judicial Activism and Conservative Politics, 73 U. CoLo. L. REV. 1139, 1144-61 (2002) (setting forth six broad categories of judicial behavior that could be characterized as activist). 